\title{
DISTRICT COOLING IN THE PEOPLE'S REPUBLIC OF CHINA STATUS AND DEVELOPMENT POTENTIAL
}

JANUARY 2017 



\section{DISTRICT COOLING IN THE PEOPLE'S REPUBLIC OF CHINA}

STATUS AND DEVELOPMENT POTENTIAL

JANUARY 2017 
(c) 2017 Asian Development Bank

6 ADB Avenue, Mandaluyong City, 1550 Metro Manila, Philippines

Tel +63 2632 4444; Fax +6326362444

www.adb.org

Some rights reserved. Published in 2017.

Printed in the Philippines.

ISBN 978-92-9257-709-4 (Print), 978-92-9257-710-0 (e-ISBN)

Publication Stock No. RPT168582-2

DOI: http://dx.doi.org/10.22617/RPT168582-2

Cataloging-In-Publication Data

Asian Development Bank.

District cooling in the People's Republic of China: Status and Development Potential Mandaluyong City, Philippines: Asian Development Bank, 2017.

1. District cooling. 2. People's Republic of China. 3. Energy efficiency.

I. Asian Development Bank.

The views expressed in this publication are those of the authors and do not necessarily reflect the views and policies of the Asian Development Bank (ADB) or its Board of Governors or the governments they represent.

ADB does not guarantee the accuracy of the data included in this publication and accepts no responsibility for any consequence of their use. The mention of specific companies or products of manufacturers does not imply that they are endorsed or recommended by ADB in preference to others of a similar nature that are not mentioned.

By making any designation of or reference to a particular territory or geographic area, or by using the term "country" in this document, $A D B$ does not intend to make any judgments as to the legal or other status of any territory or area.

This work is available under the Creative Commons Attribution 3.0 IGO license (CC BY 3.0 IGO)

https://creativecommons.org/licenses/by/3.0/igo/. By using the content of this publication, you agree to be bound by the terms of this license.

This CC license does not apply to non-ADB copyright materials in this publication. If the material is attributed to another source, please contact the copyright owner or publisher of that source for permission to reproduce it. ADB cannot be held liable for any claims that arise as a result of your use of the material.

Attribution-You should always acknowledge ADB as the source using the following format:

[Author]. [Year of publication]. [Title of the work in italics]. [City of publication]: [Publisher]. (C) ADB. [URL or DOI] [license].

Translations-Any translations you create should carry the following disclaimer:

Originally published by ADB in English under the title [title in italics]. (c) ADB. [URL or DOI] [license]. The quality of the translation and its coherence with the original text is the sole responsibility of the translator. The English original of this work is the only official version.

Adaptations-Any adaptations you create should carry the following disclaimer:

This is an adaptation of an original work titled [title in italics]. () ADB. [URL or DOI][license]. The views expressed here are those of the authors and do not necessarily reflect the views and policies of ADB or its Board of Governors or the governments they represent. ADB does not endorse this work or guarantee the accuracy of the data included in this publication and accepts no responsibility for any consequence of their use.

Please contact pubsmarketing@adb.org if you have questions or comments with respect to content, or if you wish to obtain copyright permission for your intended use that does not fall within these terms, or for permission to use the ADB logo.

Notes:

In this publication, "\$” refers to US dollars.

Corrigenda to ADB publications may be found at http://www.adb.org/publications/corrigenda

ADB recognizes "China" as the People's Republic of China. 


\section{Contents}

Abbreviations $\quad$ iv

Executive Summary

I. Background and Introduction 1

II. What is District Cooling? 3

III. Benefits and Challenges of District Cooling 5

A. Benefits $\quad 5$

B. Challenges 6

IV. District Cooling Technologies $\quad 7$

A. Cooling Source and Generating Plant 8

B. Cooling Distribution System 10

C. Energy Transfer Station $\quad 12$

V. Business Models for District Cooling 13

VI. Financial Feasibility of District Cooling $\quad 15$

VII. Regulation of District Cooling $\quad 17$

VIII. District Cooling Worldwide 19

IX. District Cooling Market in the PRC $\quad 27$

A. History of District Cooling in the PRC 28

B. Present District Cooling Market 28

C. District Cooling Regulations 29

D. Players in the District Cooling Market $\quad 29$

X. Future of District Cooling in the PRC 33

XI. Conclusions and Recommendations 35

Appendices

Appendix 1 Interview Results 38

Appendix 2 District Cooling Papers and Articles Published $\quad 46$

Appendix 3 Implemented and Ongoing Projects 47

$\begin{array}{ll}\text { References } & 50\end{array}$

Figure 1: District Cooling System 3

Figure 2: Components of District Cooling Systems $\quad 7$

Figure 3: Compressor Chiller $\quad 8$

Figure 4: Absorption Chiller 9

Figure 5: Schematic of Compressor Chiller and Absorption Chiller 9

Figure 6: Thermal Energy Storage in Raleigh, North Carolina, US 10

Figure 7: Schematic of District Cooling Distribution System 10

Figure 8: Two Separate Two-Pipe Networks 11

Figure 9: Schematic of Energy Transfer Station 12

Figure 10: Market Share of District Cooling Worldwide $\quad 19$

Figure 11: District Cooling Supply Volume, by Year 20

Figure 12: Yokohama Minato Mirai 21 District Cooling Service Area 21

Figure 13: Stockholm District Cooling $\quad 22$

Figure 14: District Cooling Supply in the European Union 23

Figure 15: Annual Increase in District Energy in North America 24

Figure 16: Chicago District Cooling $\quad 25$

Figure 17: Annual Increase in District Energy in the Middle East 26

Figure 18: District Cooling Plant in Qatar $\quad 26$

Figure 19: Climate Zones in the PRC $\quad 27$

Figure 20: Building Floor Space in the PRC 33

Figure 21: Estimated Floor Space in the PRC by 2030

Table 1: Other District Cooling Systems in Japan 21

Table 2: Other District Cooling Projects in France 22

Table 3: Other District Cooling Systems in North America 23 


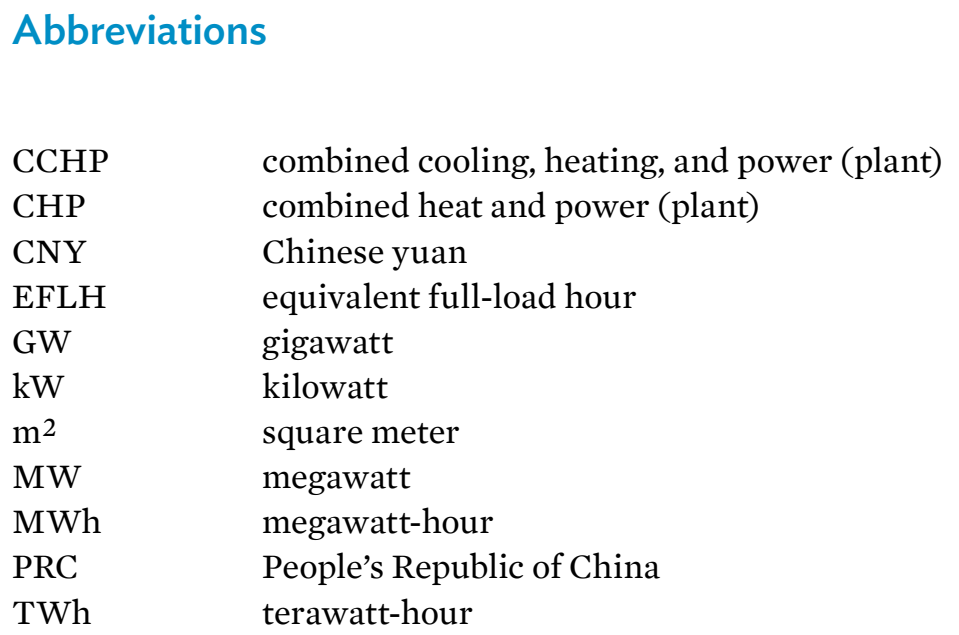




\section{Executive Summary}

District cooling is a well-known concept in the People's Republic of China (PRC), where its foundations were laid at the start of the millennium. The term is variously defined in the country. Centralized cooling systems for individual buildings or small building blocks are generally not considered to be district cooling.

Because of the unclear definition of the concept and the fact that no national organization is responsible for gathering the information and promoting the development of district cooling in the PRC, district cooling statistics are hard to find. However, distinguished experts in the district cooling field, including academics and other individuals interviewed for this study, have much experience and fact-based knowledge regarding the district cooling market. Furthermore, there is an abundance of articles on district cooling, most of them dealing with specific technologies and implemented projects.

The business climate for district cooling in the PRC is relatively similar to that in other countries, and can be described as market driven. In the absence of regulations specific to district cooling, some building codes indirectly support the energy efficiency improvements espoused by district cooling.

International best practice technologies are available, but many district cooling projects are not selected, developed, and implemented according to international standards. Questionable successes among relatively large-scale district cooling systems serving as reference points for the entire concept of district cooling have caused justifiable skepticism.

Although the relatively more mature markets in North America, the Middle East, Europe, and Japan account for over $80 \%$ of the global district cooling market, the PRC has a larger market than either Japan or Europe, and could conceivably catch up with North America within 5 years.

This study concludes that district cooling is feasible in the PRC and deserves further development because it can significantly improve the efficiency of energy use, as well as indoor climate, with energy from different sources including renewables. Commercial building blocks, such as central business districts and transit-oriented development areas, airports, hospitals, and industries with relatively high cooling demand and predictable load patterns, are the suggested target consumers.

The establishment of a national coordinating body to pursue the development of district cooling and compile a handbook of district cooling best practices for the PRC could encourage the wider adoption of district cooling in the country. Technical assistance to institutionalize the practice of district cooling in its operations would be beneficial. 



\section{Background and Introduction}

The Asian Development Bank study that led to this report was done to determine the status of district cooling in the People's Republic of China (PRC), investigate its future development potential, and identify further studies that must be carried out to promote the development of district cooling.

District cooling is based on the same general concept as district heating: distributing energy to end consumers from a centralized generation facility. Its use has grown rapidly in the past 2 decades and the technology has gained widespread acceptance worldwide.

This report defines the concept of district cooling and summarizes its benefits and challenges; presents technologies used in district cooling, including standalone, as well as integrated or cogeneration (or even trigeneration), solutions; discusses briefly several business models followed in the district cooling sector and considers the financial feasibility of district cooling projects; goes over the various regulations regarding district cooling; looks into how district cooling has developed worldwide and examines the district cooling market in the PRC in some detail; and recommends steps that should be taken for the further development of district cooling in the PRC.

The information in this report came from desk research and interviews with representatives of the various stakeholders in the PRC's district cooling sectorgovernment bodies, associations, universities and research entities, district cooling operators, and engineering companies, among others. 



\section{What is District Cooling?}

In this report district cooling is defined as "one cooling network, distributing chilled water to more than one building." This definition has some, but not total, market acceptance, as the interviews indicated. The term is also defined elsewhere as one cooling network, distributing cooling water to more than one customer. At first glance, these definitions do not seem to be much different. But the alternative definition excludes facilities like airports, hospitals, and universities, where cooling is distributed to only one customer managing several buildings.

The same basic concept underlies district cooling and district heating. Both distribute centrally generated energy to large or small communities through a pipe network. Both are subsumed under the umbrella term "district energy."

District cooling systems, large or small, produce energy at one or more central production sites and use many different cooling technologies, including individual chiller, combined heating and cooling, and combined cooling, heating, and power (CCHP) systems (Figure 1). The technologies, energy sources, and combinations of these are described in some detail in section IV of this report.

Figure 1: District Cooling System

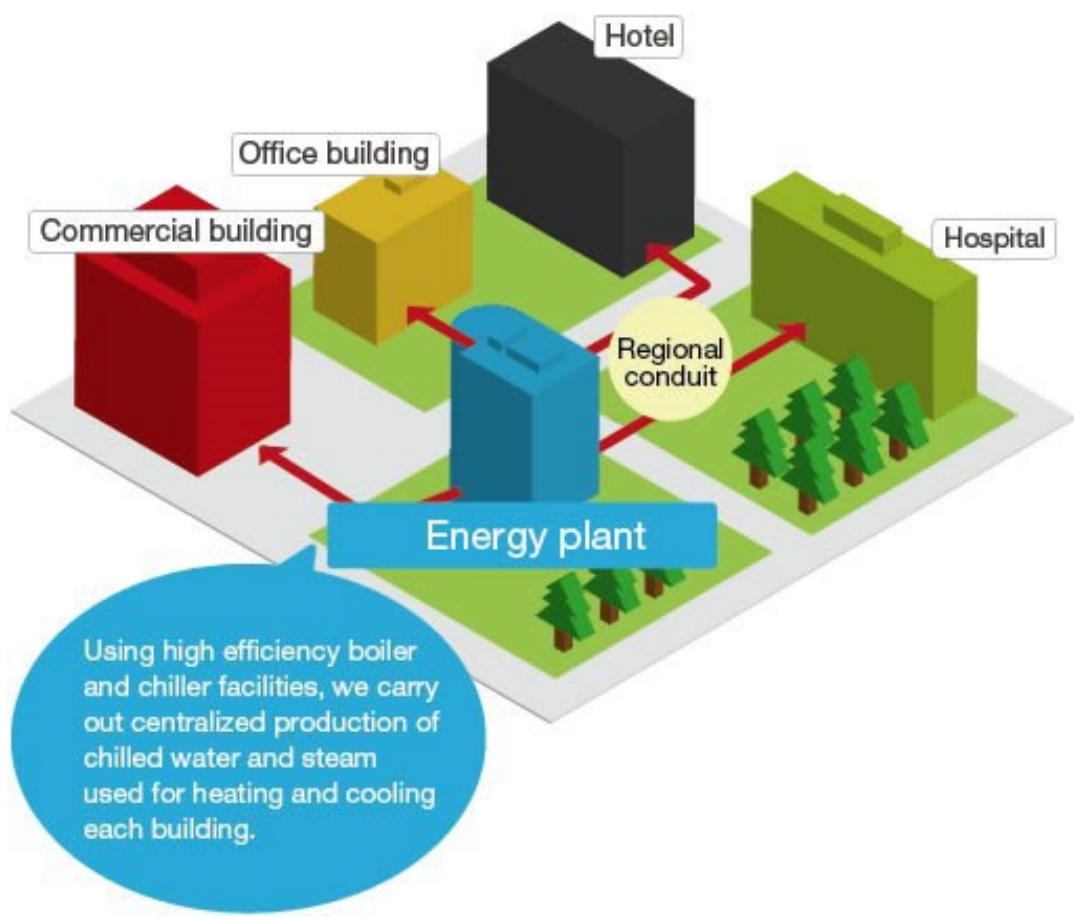


The main benefits provided by district cooling systems are:

- multi-energy systems, using several energy sources (including energy from waste) and thus optimizing resource availability and reducing operating and environmental costs;

- optimized capital expenses, as a result of variations in operating scale and in load demand;

- optimized operating expenses, through increased system efficiency;

- centralized system management, operation, and maintenance by capable and efficient professionals, optimizing the life-cycle cost; and

- high system efficiency, with low use of primary energy and reduced emissions.

In sum, a district cooling system is an energy generation and distribution system that offers substantive efficiency gains by virtue of its larger scale (compared with individual cooling solutions); the possibility of using several energy sources and thus improving environmental and cost performance; and the potential for integration with other energy systems, such as district heating, steam, power distribution, and gas systems.

On the other hand, although district cooling systems can be considered successful worldwide and the technologies are mature, many challenges stand in the way of their adoption. The socioeconomic benefits, often long term and related to energy and environmental efficiency, are not always reflected in specific business cases or at the individual business level. Initial investments are relatively high, and rely on initiatives from governmental bodies and investors, rather than individuals. Moreover, cooling, unlike heating, water, and electricity, is often perceived as a luxury or comfort service, rather than a basic utility need. 


\section{Benefits and Challenges of District Cooling}

This section gives a brief rundown of the benefits and challenges of district cooling, as brought out in the desk research and the interviews summarized in Appendix 1.

\section{A. Benefits}

The technical, environmental, and financial performance of centralized production facilities is, by nature, easier to control. Below are some benefits of district cooling systems found during the study.

\section{Financial and economic benefits}

- lower investment in production plant due to economies of scale

- lower installed capacity due to coincidence factor (local peak demand occurs at different times) and use of thermal energy storage

- longer life span and lower maintenance cost

- financial and economic benefits due to energy efficiency

Energy efficiency

- $\quad 25 \%-50 \%$ increase in energy efficiency due to economies of scale and part-load efficiency, compared with split-type air-conditioning units and centralized cooling systems for individual buildings

- up to $10 \%$ increase in energy efficiency due to reduction of urban heat island effect induced by split-type air-conditioning units and centralized cooling systems for individual buildings

- use of different energy sources and technologies, such as waste heat from industrial processes and power generation, and curtailed wind energy, thus improving energy efficiency from a global perspective

\section{Environmental efficiency}

- use of various renewable energy sources

- less noise pollution

- less refrigerant use or leakage

Other benefits

- improved comfort

- improved indoor climate

- reliability

- increased availability of space in individual buildings (as a result of centralized cooling, with attendant economies of scale) 


\section{B. Challenges}

Centralized energy infrastructure normally needs a great deal of planning and integration of interface stakeholders. Below are some challenges facing district cooling systems development.

\section{End-user challenges}

- consumer protection measures related to pricing and quality of service

- general acceptance of added value of improved indoor climate

\section{Financial and economic challenges}

- relatively high cooling demand density required for financial feasibility

- acceptance and application of connection fees to allow the investment cost to be shared with developers and end users

- front-loaded investments (partly for the production facility, but mainly for the distribution system)

- electricity tariff and subsidy differences between electricity for household use and electricity for commercial and industrial use

- competitive gas tariffs and subsidies

- high price of land for centralized cooling station

Planning and design challenges

- integration of infrastructure planning with municipal development planning

- design criteria for real-estate developers

- overestimation of cooling load and required cooling

- cooling load buildup

- user behavior and occupancy rate

\section{Project implementation challenges}

- simple and straightforward business models

- realistic planning and design

- realistic and well-prepared feasibility studies

- off-taker commitments

- energy-efficient and feasible district cooling concepts professional implementation along the project value chain, including planning, design, procurement, construction, installation, commissioning, and operation and maintenance 


\section{District Cooling Technologies}

This section describes district cooling systems and the technologies generally used. Best practices are presented briefly here; details can be found in the District Cooling Best Practice Guide compiled by the International District Energy Association. These practices are mostly applicable anywhere, with minor exceptions. For example, thermal storage is more feasible in locations where electricity tariffs vary from day to day.

A district cooling system has three main components (Figure 2): a cooling source and generating plant, a cooling distribution system, and an energy transfer station with heat exchangers.

\section{Figure 2: Components of District Cooling Systems}

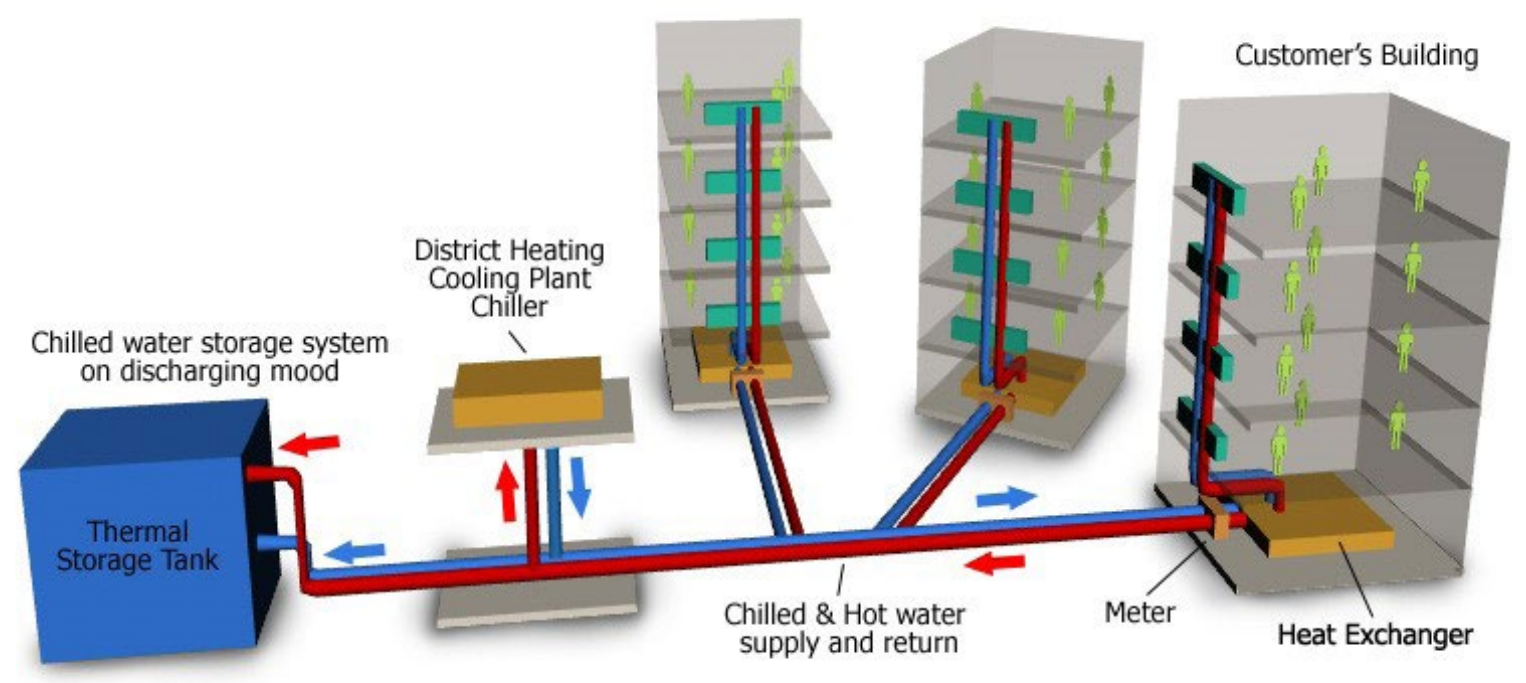

Source: International Energy Administration (IEA) District Heating and Cooling.

A district cooling system can be part of an upstream system, either supplying energy to a cooling plant or included in a cogeneration or trigeneration system. Below are some examples of upstream systems:

- heating systems

- district heating

- recovery and use of surplus heat from industry 
- electricity generation systems

- electric power grid

- electricity generated directly from renewable energy sources, such as hydro, wind, and solar power

- cogeneration and trigeneration systems

- CCHP

- district heating and cooling

Directly or indirectly, the district cooling system can be based on many different fuels, such as fossil fuels (coal, oil, gas); renewable energy (biomass, wind, solar, hydro, geothermal energy); and energy from municipal solid waste and industrial waste. The efficiency of district cooling technologies, which varies widely, determines the extent of emissions from the district cooling system, in combination with the fuels used.

\section{A. Cooling Source and Generating Plant}

The plant can be equipped with compressor chillers, heat-driven absorption chillers, or heat exchangers (for free cooling; see below), or with a combination of these technologies. The cooling source and the major equipment in the plant will depend on available resources and their cost, and on local conditions.

In addition, thermal energy storage will optimize the performance of the chillers, enable the plant to use cheaper electricity when prices go down, and act as cooling source during periods of peak demand or provide cooling redundancy and thereby reduce the required chiller capacity.

Compressor chillers. A compressor chiller is similar to a heat pump with a compressor, a condenser, an expansion valve, and an evaporator. Compressor chillers use different types of heat sinks, or passive heat exchangers (Figure 3). The most common heat sinks for district cooling projects are air, wastewater, river water, lake water, seawater, groundwater, and treated sewage water.

\section{Figure 3: Compressor Chiller}

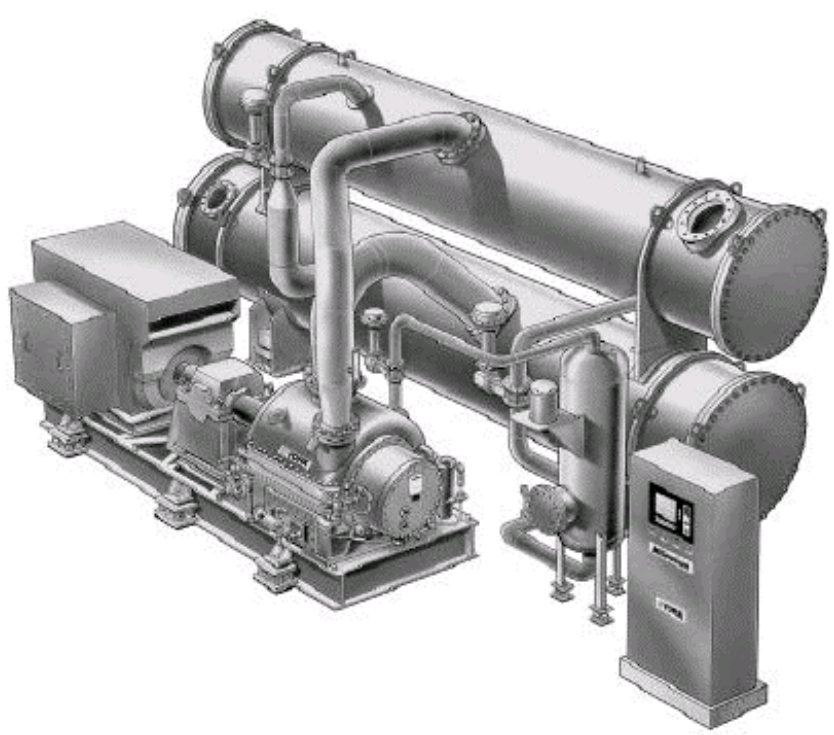

Source: Cappela Energy, India. 
Absorption chillers. An absorption chiller is similar to a compressor chiller, where the compressor has been replaced by an arrangement of generator, pump, absorber and absorbent (Figure 4). Instead of a compressor driven by electricity or steam, the absorption chiller uses hot media-commonly steam, hot water, or gas-to drive the cycle. Heat sinks used for absorption chillers are similar to compressor chillers (described above).

\section{Figure 4: Absorption Chiller}

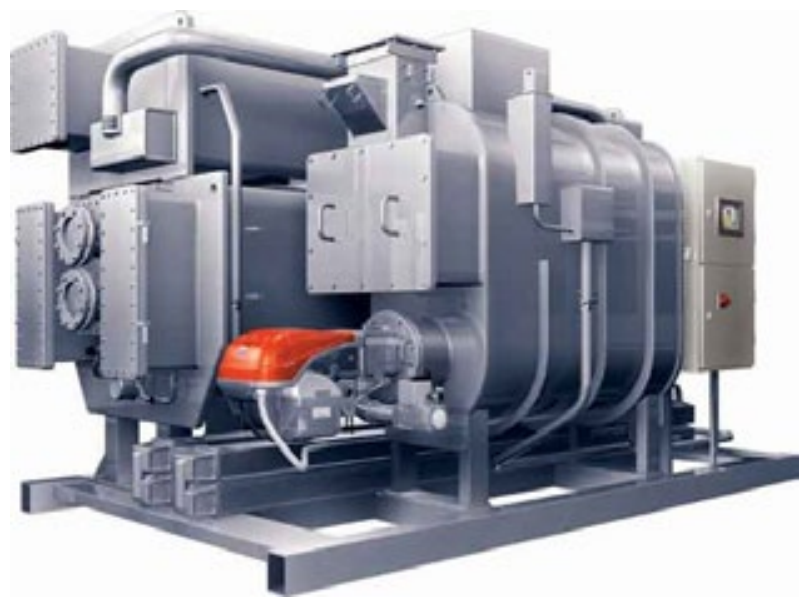

Source: Shuangliang Eco-Energy Systems, PRC.

Figure 5 illustrates the basic components of a compressor chiller (left) and an absorption chiller (right).

Figure 5: Schematic of Compressor Chiller and Absorption Chiller

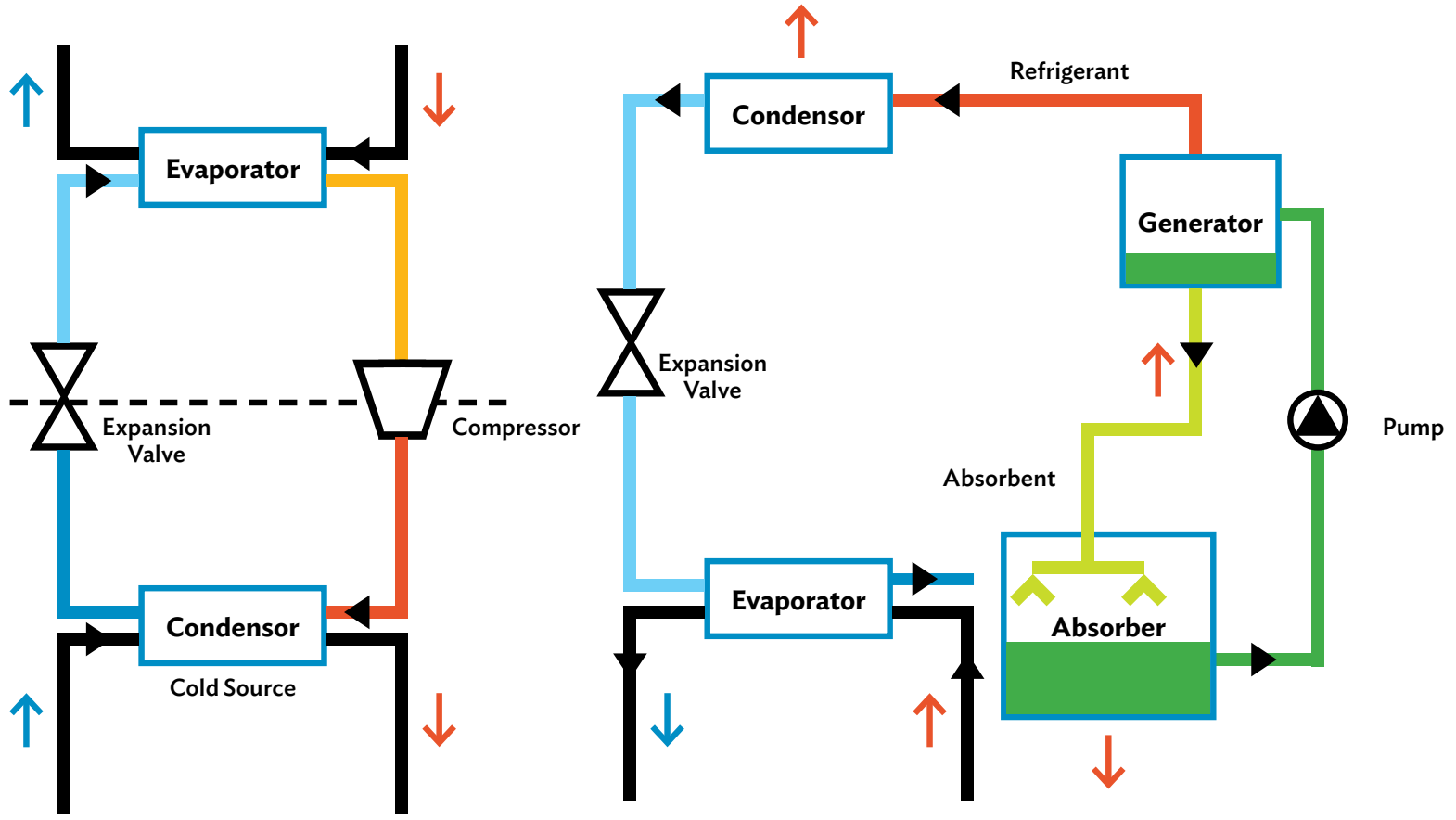

Source: Ruitengmao Energy Conservation, PRC. 
Free cooling. The direct use of a heat sink, such as seawater or lake water, in a district cooling system, without a chiller, is known as free cooling.

Thermal energy storage. Thermal storage for district cooling is often divided into two main categories: ice storage and chilled water storage (Figure 6). In general, ice storage requires less storage tank volume than chilled water storage and can deliver water at a lower temperature.

Figure 6: Thermal Energy Storage in Raleigh, North Carolina, US

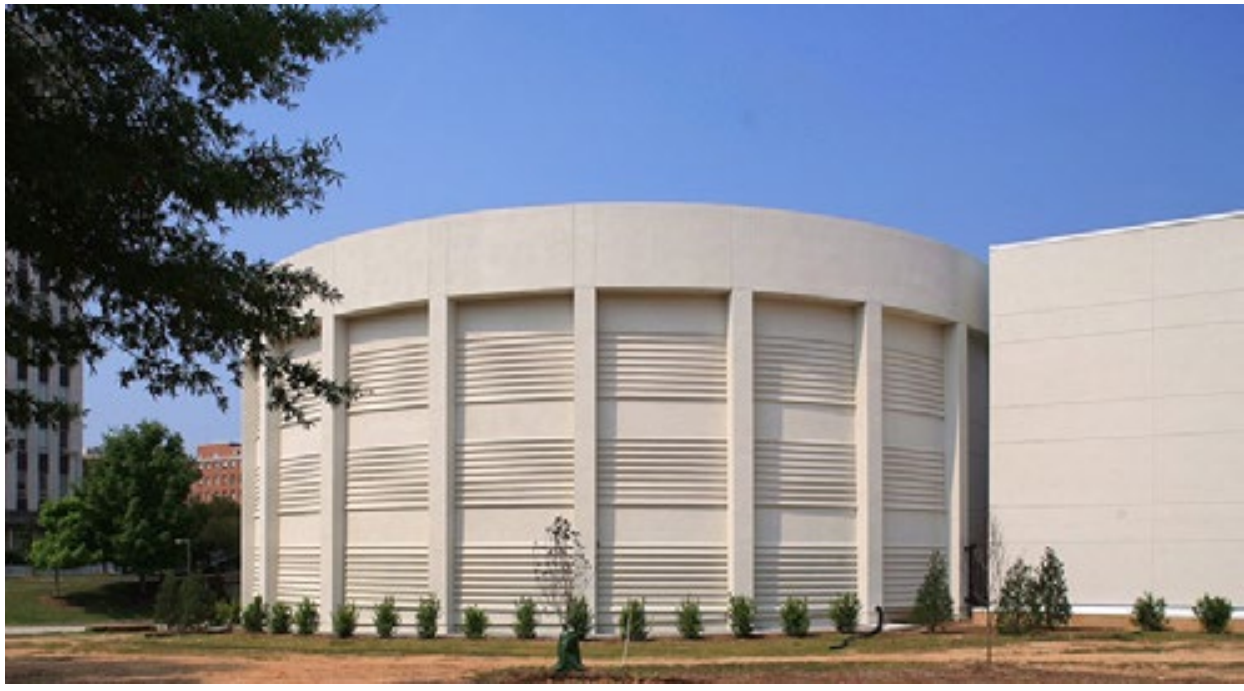

Source: DN Tanks.

\section{B. Cooling Distribution System}

District cooling distribution systems (Figure 7) are similar to district heating systems, but the capital costs per unit volume of distributed energy are higher for district cooling systems because of the low temperature difference in the systems. On the other hand, cooling pipes require less insulation and are therefore slightly cheaper than heating pipes.

Figure 7: Schematic of District Cooling Distribution System

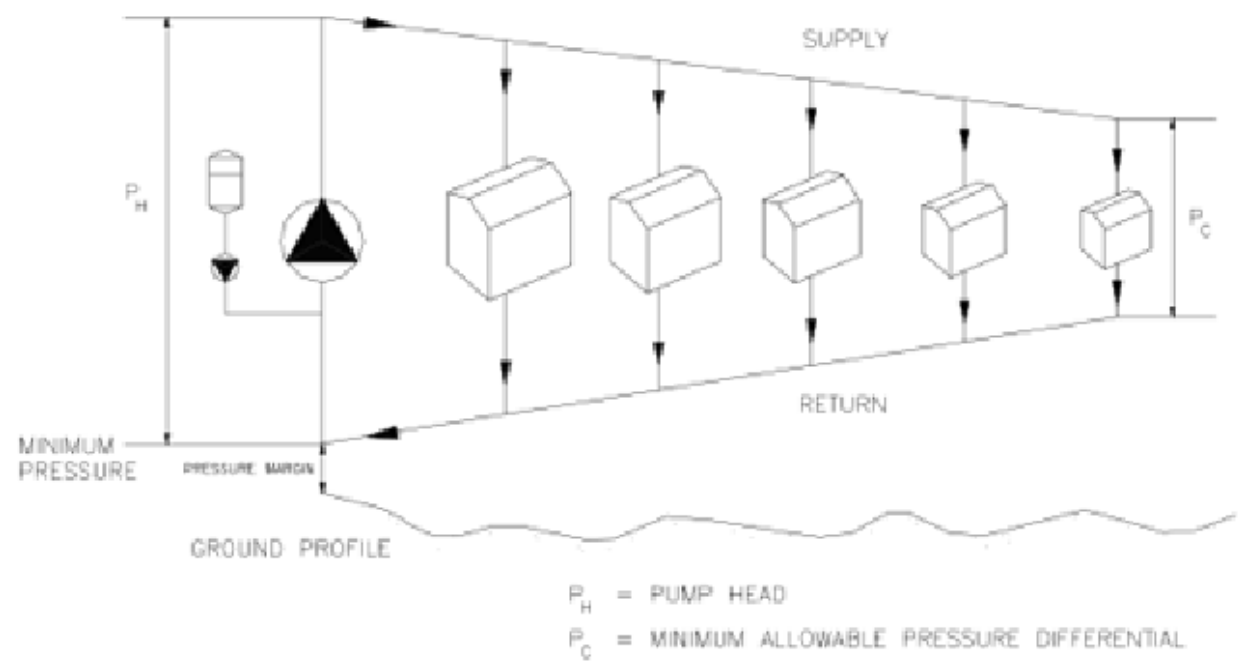


There are three main design concepts for district cooling distribution systems:

- a single two-pipe network used for heating during winter and cooling during summer

- two separate two-pipe networks for heating and cooling all year round

- two separate two-pipe networks for seasonal heating and cooling, comprising a larger network for heating during winter and cooling in the summer season, and a smaller network for cooling during winter and heating during summer (Figure 8)

\section{Figure 8: Two Separate Two-Pipe Networks}

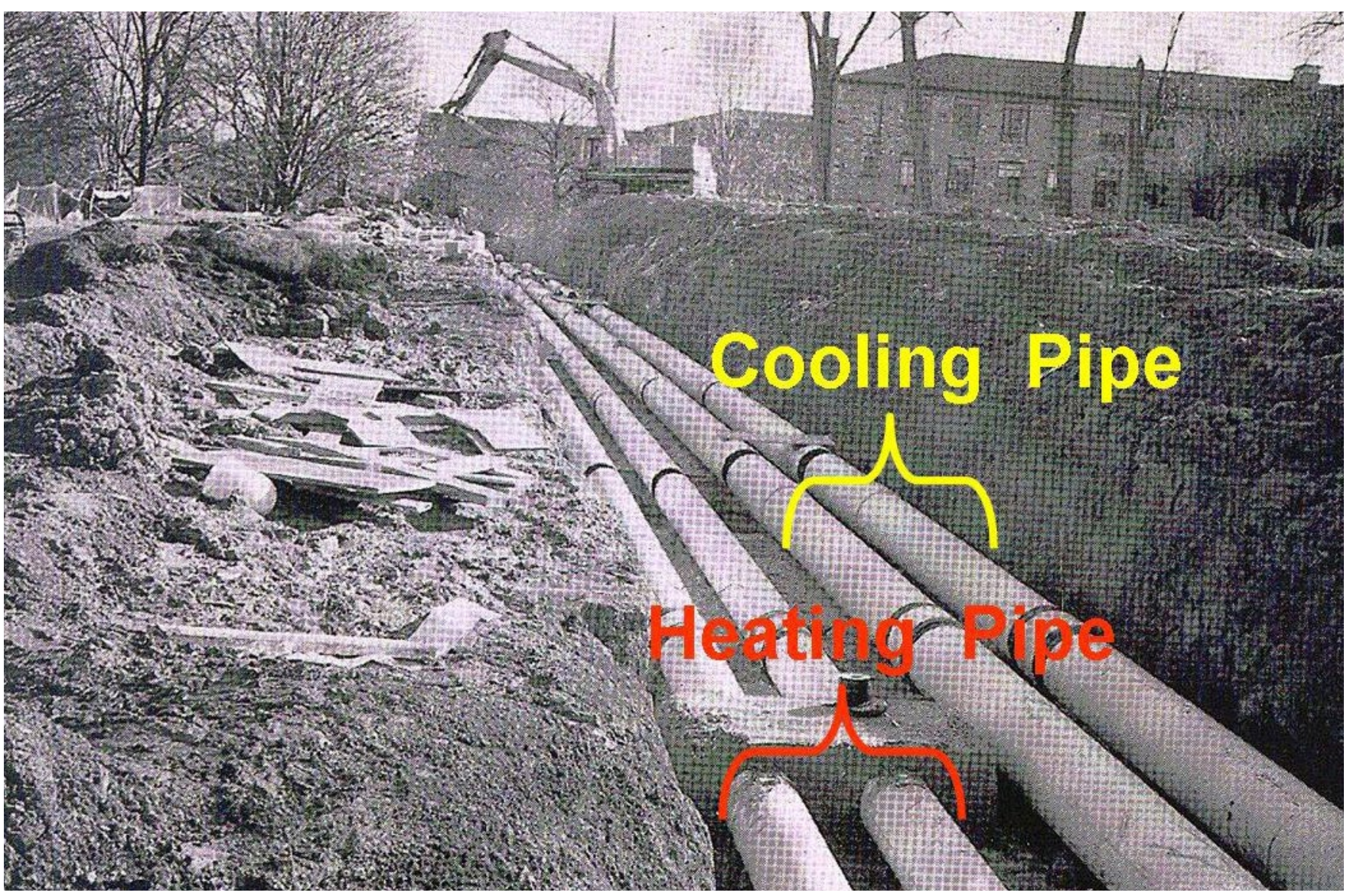

Source: BPM Select.

Each design concept has its strengths and weaknesses in terms of function and investment costs. The first concept is relatively common in the PRC, while the second is most prevalent in Europe and North America. A single two-pipe network will not allow a full year of operation for both heating and cooling. The third option is applicable in places where the heating and cooling loads in different seasons are favorable, and is applied in several projects in the PRC.

Insulated piping buried directly in the ground is preferred over the costlier alternatives of encasing the pipes in concrete ducts or building underground utility tunnels. Implementing a leak detection system in the distribution system to detect leaks and monitor water consumption in the system is recommended. 


\section{Energy Transfer Station}

The energy transfer station separates the building's internal systems from the district cooling distribution system, and mainly consisting of a heat exchanger unit with measurement (meters and transmitters) and control (pump, valves) equipment (Figure 9).

\section{Figure 9: Schematic of Energy Transfer Station}

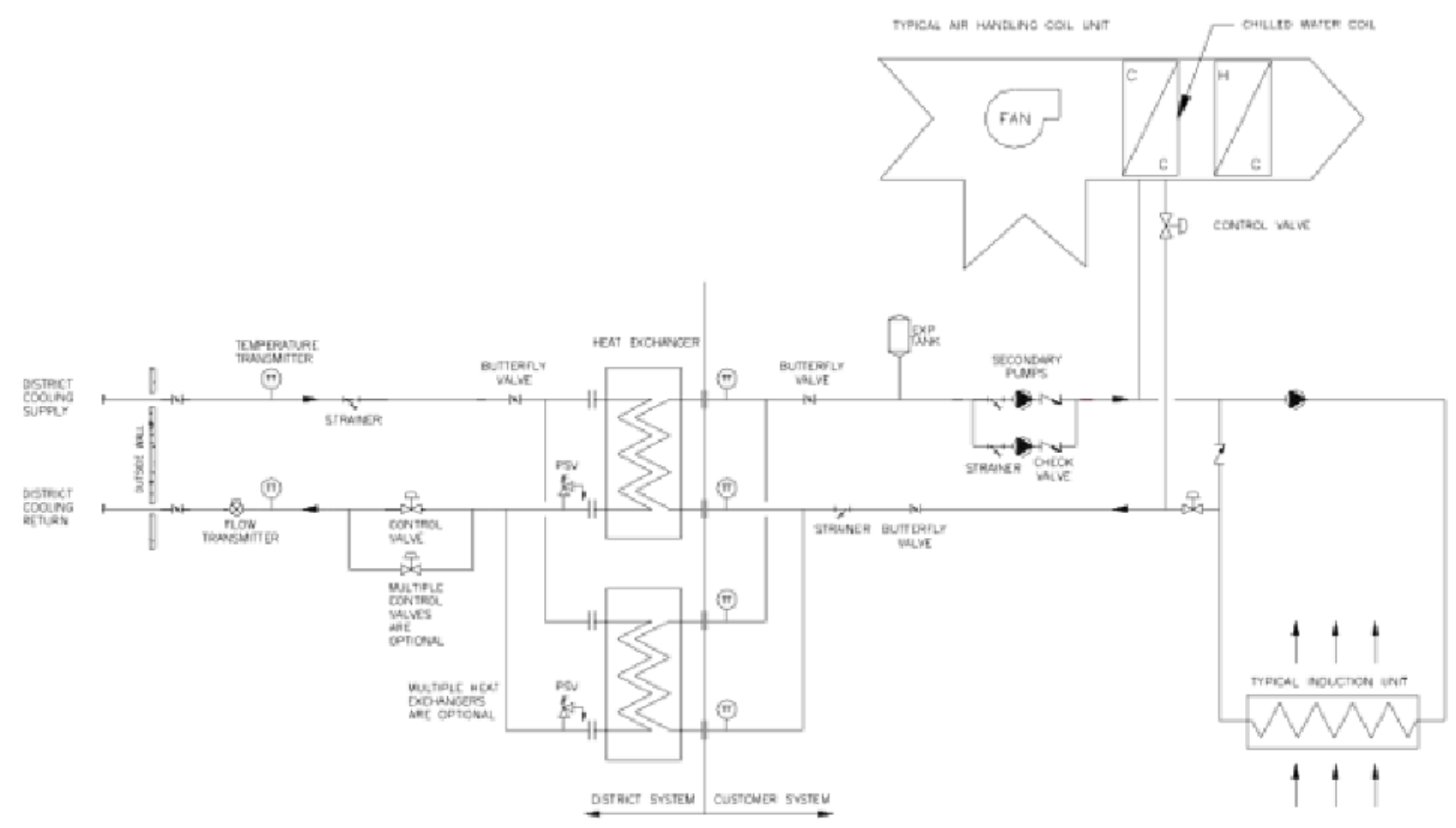

Source: IEA. 


\section{Business Models for District Cooling}

The business model for district cooling can vary from case to case. A utility company-often, an electricity, district heating, or gas utility company-invests in a district cooling system, acts as asset manager, and operates and maintains the system.

In some cases, there are several co-investors, or the utility company only operates and maintains the district cooling system. A utility company could provide only operation and maintenance services with or without performance guarantees. The performance guarantee could be a guaranteed energy performance contract, an energy performance contract with key performance indicators, or an energy saving contract.

A district cooling company could also be established by a real estate developer to provide cooling services in its development areas, perhaps in combination with electricity and gas utility companies and the municipal government. 



\section{Financial Feasibility of District Cooling}

For district cooling projects to be feasible, the value of the benefits gained, either functional or economical, must be competitive with that offered by alternatives.

The total cost of a cooling system depends on many factors, such as required capacity (in megawatts [MW]), size of distribution system, diversity (coincidence) factor, cooling temperature, availability requirements, ambient air conditions, local legislation, availability of space and price of land, and local labor costs and construction costs. All of these factors are, to some extent, location specific.

District cooling cost has four main components: production plant cost, distribution system cost, energy transfer station cost, and project development cost. Production plant, energy transfer station, and project development costs are relatively linear and can be expressed in Chinese yuan (CNY) per kilowatt $(\mathrm{kW})$. Distribution system cost, however, depends very much on energy density. In Europe, the term "pipeline density" (kWcool / mdistribution pipe and kW/ hourcool / mdistribution pipe) is a common benchmark for evaluating the feasibility of district cooling projects. The benchmark value depends on local conditions, but should normally be above $3 \mathrm{~kW}$ per meter and 4 megawatt-hours (MWh) per meter.

From a consumer perspective, affordability and value for money have a significant bearing on district cooling decisions. Consumers for whom improved indoor climate, in terms of reliability and well-distributed cooling in end-user space (a great portion of residential buildings), is not a priority may well consider traditional split air-conditioning as an alternative to district cooling.

Given a declared coefficient of performance (COP)cool of 3 for affordable traditional split-type air-conditioning units, and an estimated annual COPcool of 2, the cooling cost would be CNY200/MWh at an electricity price of CNY400/MWh. District cooling tariffs for some district cooling projects in the PRC are listed below for comparison:

- Commercial area, Shanghai: CNY830/MWh

- Industrial zone, Qingdao: CNY450/MWh

- Commercial area, Chengdu: CNY324/MWh

Differences in the price of electricity partly explain the higher cooling cost of district cooling systems relative to that of split-type air-conditioning in the PRC. Split-type units in residential buildings benefit from the relatively low price of household electricity. The price of electricity used for district cooling, on the other hand, is based on the price charged to industrial consumers or on the cost of own production of electricity in a natural gas trigeneration plant. 
District cooling systems have a life span of up to 50 years (30 years in financial analysis reports in Europe, and 20 years in the PRC), compared with about 10 years for split-type air-conditioning units.

The initial investment cost for a district cooling system is about 2.5 times higher than that for split-type units (Yang et al. 2001), but taking the expected life span into account considerably reduces the difference in investment cost. 


\section{Regulation of District Cooling}

District cooling regulation worldwide can be divided into three main categories: social regulation, economic regulation, and market-driven regulation.

As a rule, social regulation is heavily influenced by political decisions and is most common where government (state or municipal) ownership dominates. The district heating sector in the PRC have traditionally been socially regulated but are now in transition as a result of various reforms.

Economic regulation of the district energy sector, such as that in Denmark, is usually aimed at achieving reasonable costs and price transparency, and controlled by separate energy regulators.

Market-driven regulation, normally with no (or very little) political influence, is most common in countries where the sector is competitive and has a good reputation. District energy regulation in Sweden is market driven.

These different categories have their pros and cons when it comes to efficiency incentives (technical and environmental), pricing, administrative costs, business environment, and public acceptance. District energy is viewed as a natural monopoly in most countries. Sweden has implemented third-party access to transmission and distribution systems to prevent monopoly. 



\section{District Cooling Worldwide}

District cooling was commercialized in the middle of the 20th century, about a hundred years after district heating. It scored a major breakthrough in the 1990s, when many district cooling systems were implemented worldwide. Today, district cooling is relatively common in North America, Europe, the Middle East, and Japan. Figure 10 shows the share of different regions worldwide in the district cooling market.

Figure 10: Market Share of District Cooling Worldwide

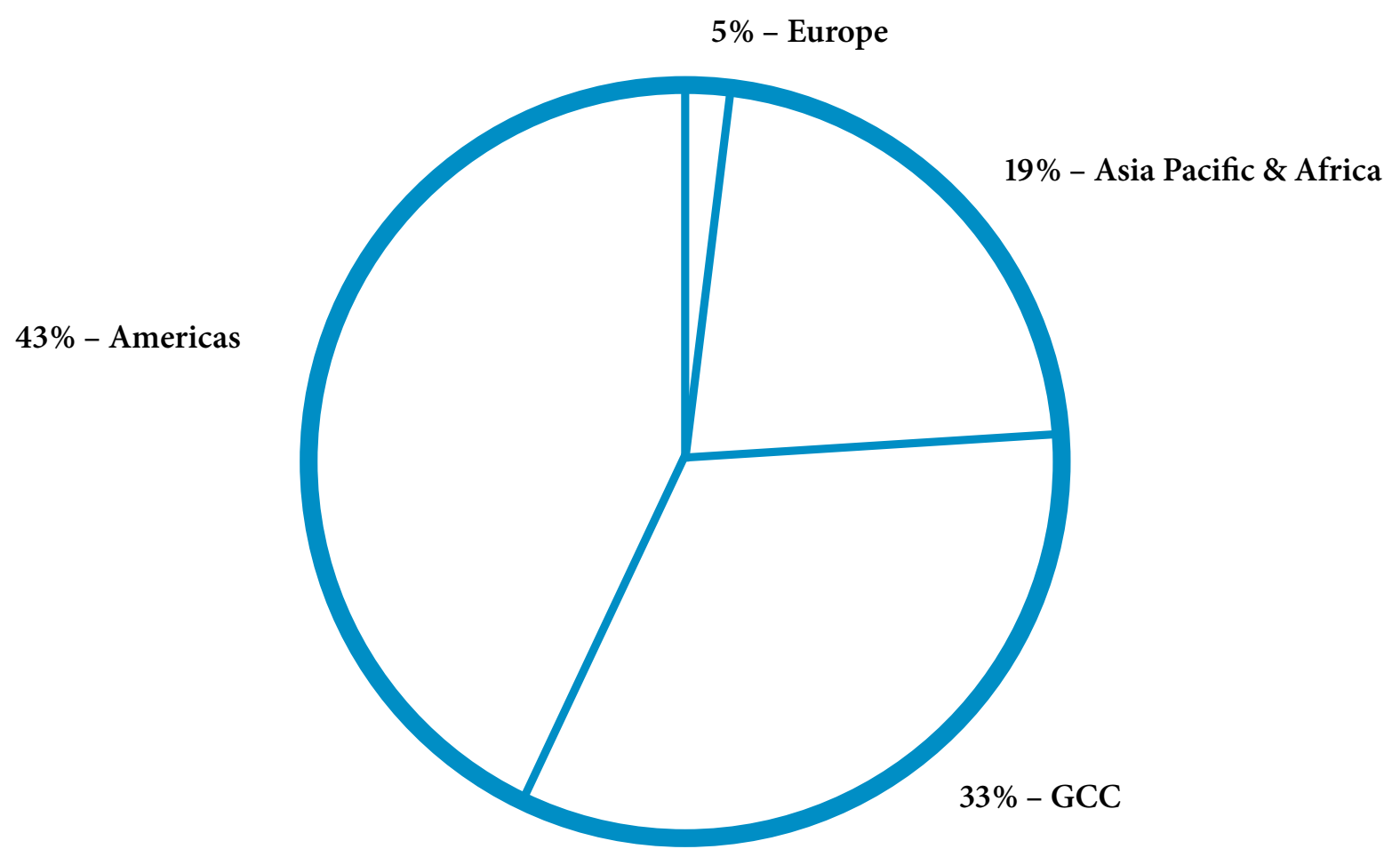

Source: Marafeq Qatar (2015). 
Best practices in these markets (covered in section IV, District Cooling Technologies) are quite similar. District cooling systems in all these countries are most commonly found in urban areas with high-density cooling needs. Commercial buildings, and public buildings to some extent, are the usual consumers of district cooling. Except in the Middle East, district cooling often coexists with district heating systems. In North America, district heating and cooling systems are typically developed for building clusters in larger cities, educational and research facilities, and military and commercial airports.

Japan. The country's first district heating and cooling systems were set up on the site of the Osaka Expo in 1970. Environmental pollution on the heels of rapid economic growth was becoming a serious issue, and air pollution in particular was more strictly regulated. Many local governments, including those in Tokyo and other metropolitan areas, were speeding up the adoption of district heating and cooling systems as an effective measure against air pollution. Today the cities of Tokyo, Osaka, Sapporo, Nagoya, Fukuoka, and Yokohama have large-scale district cooling systems. Eighty-six heat supply operators cover 148 service districts-12 in Hokkaido, 89 in the Tohoku and Kanto regions, 12 in the Chubu region, 27 in the Kinki-Chugoku-Shikoku region, and 8 in the Kyushu region. Service buildings have a total surface area of 48.67 million square meters $\left(\mathrm{m}^{2}\right)$ and a total pipeline length of $710 \mathrm{~km}$. District cooling supply in Japan is about 6.9 terawatt-hours (TWh), or 25 petajoules, yearly (Figure 11).

Figure 11: District Cooling Supply Volume, by Year

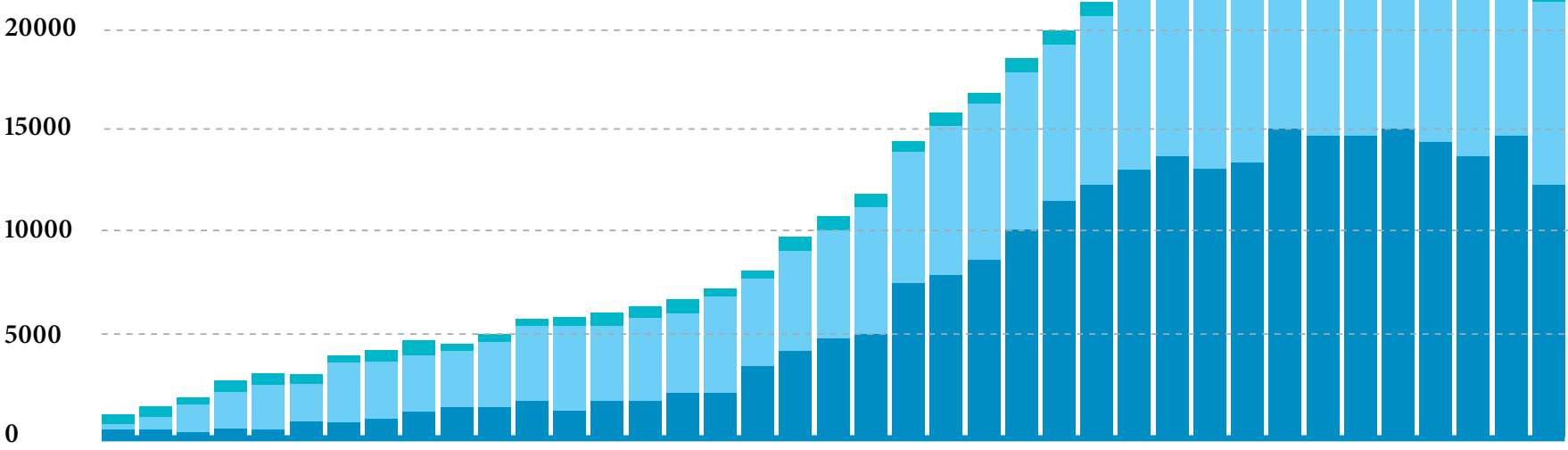

Source: Japan Heat Supply Business Association.

Together with natural gas cogeneration, heat pumps have been adopted in Japan for the recovery of heat from urban exhaust systems and untapped low-temperature heat reservoirs, such as river water, seawater, and air. Waste incineration, wastewater, and subways are sources of urban exhaust heat (Japan Heat Service Utilities Association 2008). 
Shinjuku, a major shopping, entertainment, and business district in Tokyo's central northwest, is home to many tall skyscrapers, including two office towers of the Tokyo metropolitan government.1 One of Japan's district-wide heating and cooling systems operates here. The system supplies cold water and steam generated with natural gas to buildings in the service area for air conditioning. The cooling capacity of $229 \mathrm{MW}$ over a total service floor area of 2.2 million $\mathrm{m}^{2}$ is the largest capacity in Japan and one of the largest in the world. ${ }^{2}$ Other district cooling systems in Japan are shown in Table 1 and Figure 12.

Table 1: Other District Cooling Systems in Japan

\begin{tabular}{lc}
\hline Location & Cooling Capacity (MW) \\
\hline Yokohama Minato Mirai 21 & 56 \\
\hline Tokyo-Hikarigaoka Housing Complex & 103 \\
\hline Osaka-Kansai Airport & 89 \\
\hline Downtown Sapporo & 19 \\
\hline Fukuoka-Seaside Momochi & 24 \\
\hline Osaka Senri New Town & 70 \\
\hline
\end{tabular}

$\mathrm{MW}=$ megawatt.

Source: Japan Heat Supply Business Association.

Figure 12: Yokohama Minato Mirai 21 District Cooling Service Area

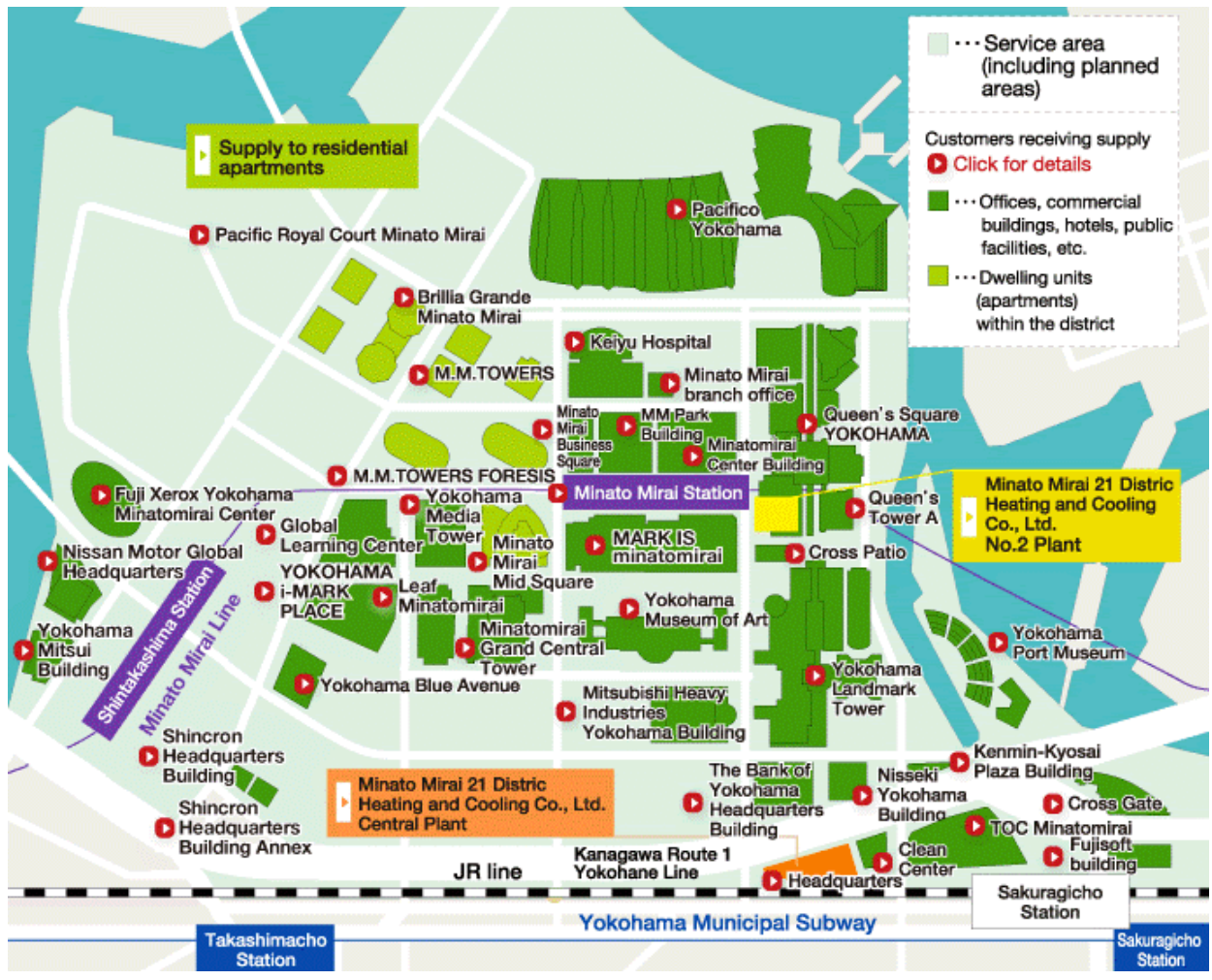

Source: Minato Mirai 21 District Heating and Cooling.

According to an energy conservation survey by Japan's Ministry of Economy, Trade and Industry (JFS 2009), district heating is generally 12\% more energy efficient than individual systems installed in individual buildings. ${ }^{3}$ It is $15 \%$ more energy efficient with a cogeneration system reusing exhaust heat, and $22 \%$ more energy efficient when using energy that would otherwise be untapped. Energy savings realized through district heating average about $15 \%$.

1 Japan for Sustainability (JFS). 2009. Japan's District Heating and Cooling Systems. JFS Newsletter, No. 82 (June). http://www.japanfs.org/en/news/archives/news_id029184.html 
Europe. The largest district cooling systems in Europe are in Stockholm and Paris. Together, these systems account for $60 \%$ of district cooling supply in Europe. France has 17 district cooling systems. In the major business district of La Défense, served by one of the world's largest networks and also the largest in Europe, planning for district heating and cooling started in 1963. The total installed air-conditioning capacity based on district cooling is $243 \mathrm{MW}$. Other district cooling projects in France are shown in Table 2.

Table 2: Other District Cooling Projects in France

\begin{tabular}{lc}
\hline Project & Cooling Capacity (MW) \\
\hline City Center of Paris & 92 \\
\hline Monaco & 36 \\
\hline Bordeaux Airport & 24 \\
\hline
\end{tabular}

$\mathrm{MW}=$ megawatt

Source: Energyland.

District cooling has developed rapidly in Sweden since the early 1990s. The country's first district heating and cooling plant was commissioned in 1992 in the city of Västerås in central Sweden. Now there are 16 district heating and cooling networks. Seven million $\mathrm{m}^{2}$ of commercial area in the Swedish capital is supplied with district cooling via the cooling distribution network, which is 76 kilometers long (Figure 13).

\section{Figure 13: Stockholm District Cooling}

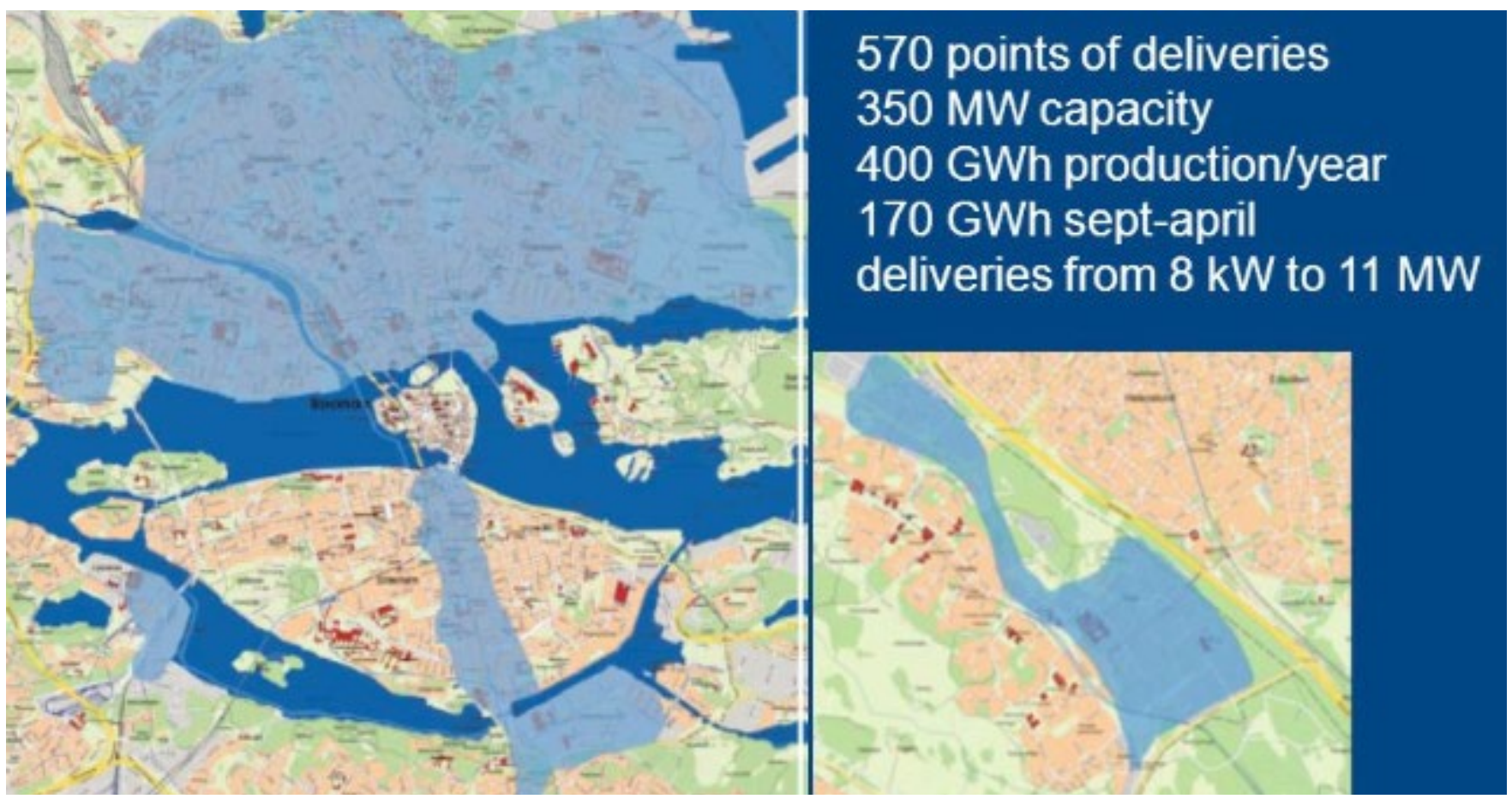

Source: Fortum Oyj, Finland.

District cooling supply in EU-274 is about 3 TWh yearly (Figure 14). It covers 1\% of the total district cooling market in EU-27 (300 TWh), and $0.2 \%$ of the potential district cooling market (about 1,220 TWh). 
Figure 14: District Cooling Supply in the European Union

1200

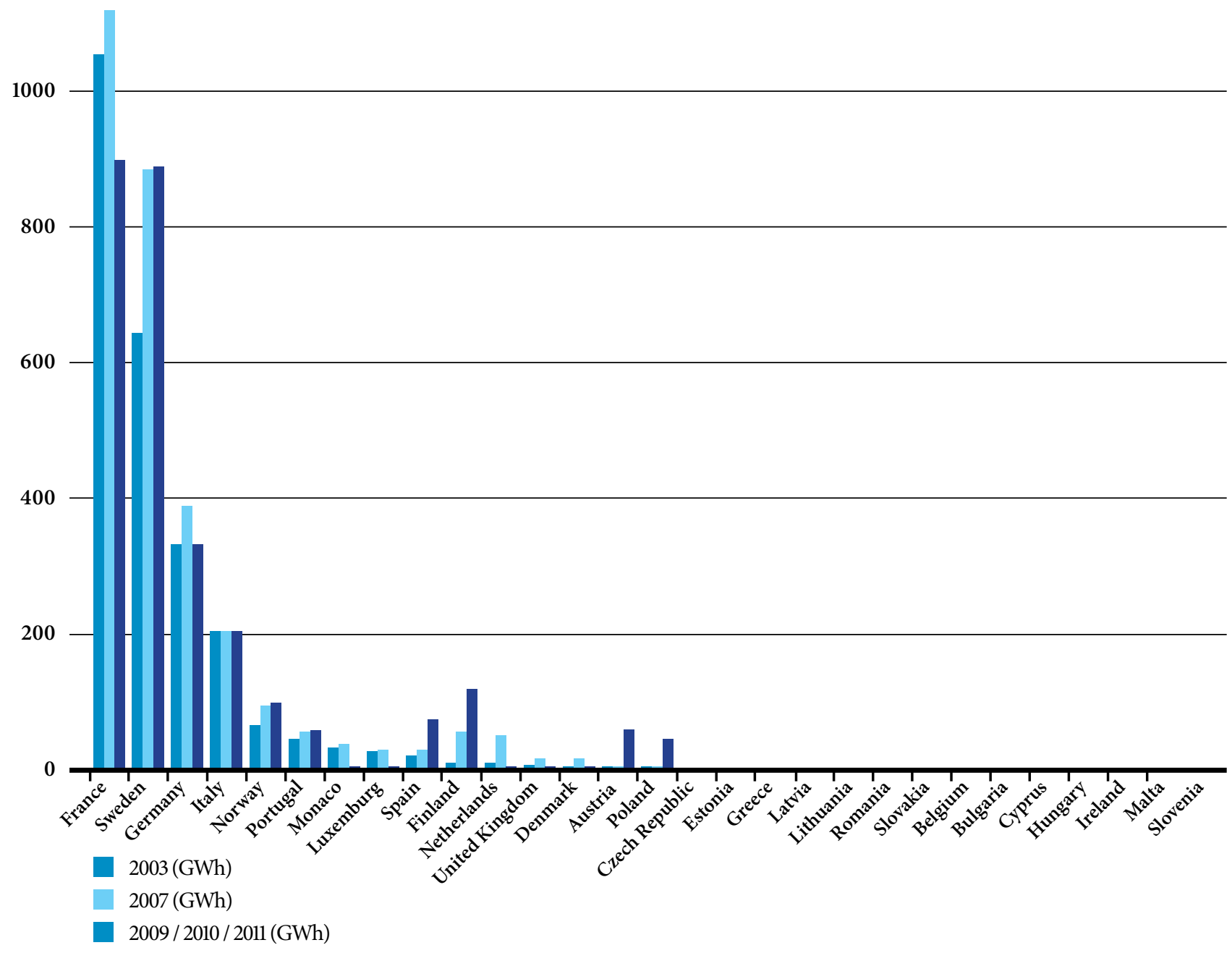

Source: RESCUE (2014).

North America. The first commercial district cooling system in North America was established in 1962 in Hartford, Connecticut. Today nearly 400 district cooling systems serve cities and campuses in North America. 5 Other district cooling system projects in North America are shown in Table 3.

\section{Table 3: Other District Cooling Systems in North America}

\begin{tabular}{lc}
\hline Project & Cooling Capacity (MW) \\
\hline Boston & 366 \\
\hline Downtown Chicago & 349 \\
\hline New York International Business Center & 172 \\
\hline Pentagon & 132 \\
\hline Denver Airport & 42 \\
\hline Cleveland, Ohio & 35 \\
\hline New York Kennedy Airport & 35 \\
\hline
\end{tabular}

$\mathrm{MW}=$ megawatt.

Source: Electrical and Mechanical Services Department, Hong Kong Special Administrative Region, PRC.

5 http://www.enwavechicago.com/about-enwave-chicago/district-cooling-industry/ 
The statistics in Figure 15 show the annual increase in district energy, including both heating and cooling, in North America.

Figure 15: Annual Increase in District Energy in North America

\section{District Energy Industry Growth: North America (Thousand sq $\mathbf{m}$ customer bldg space connected/committed) Aggregate SF reported 2000-2014}

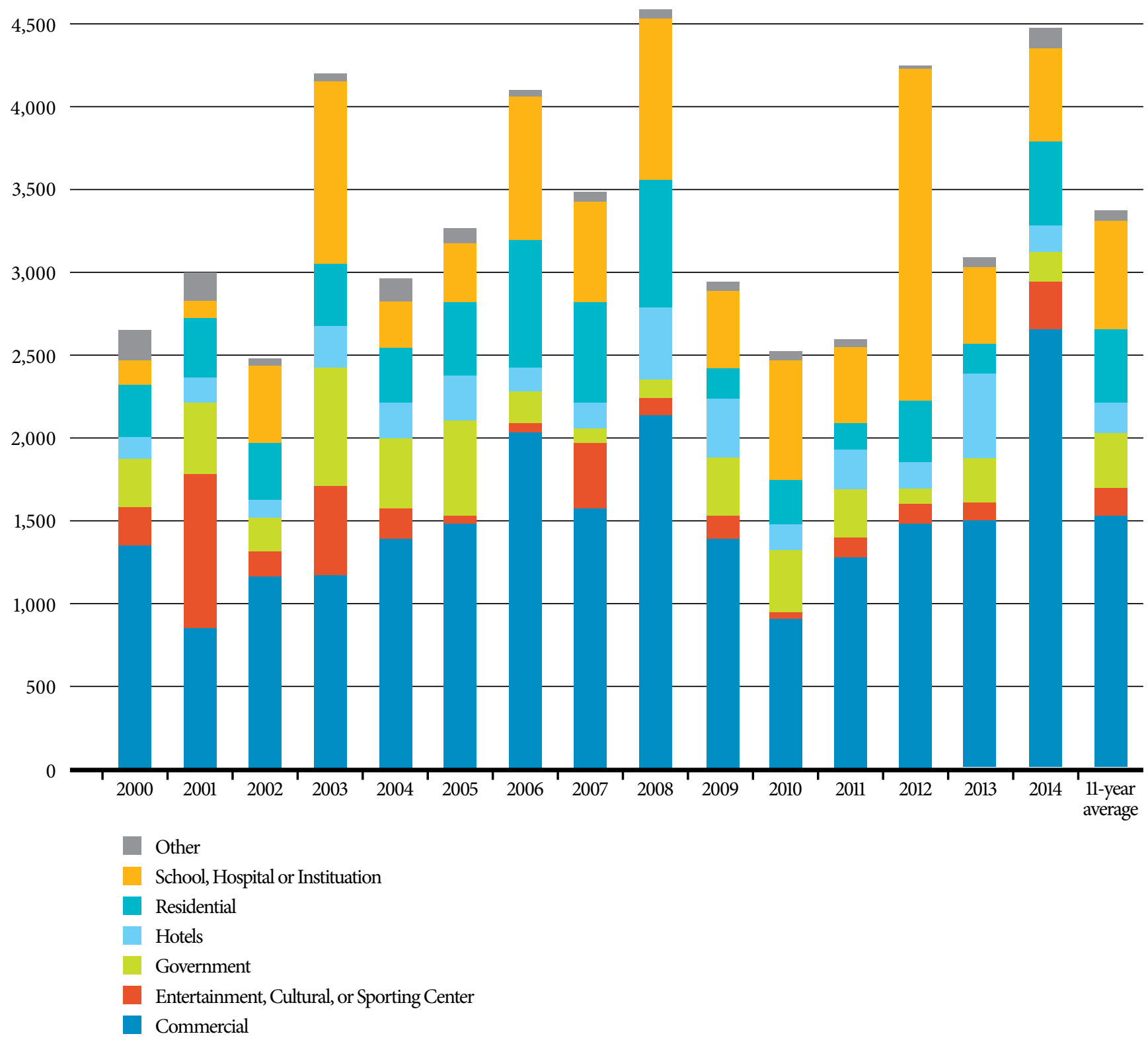

North America has some 18 gigawatts (GW) of installed district cooling capacity. Because of climate variations, the value for equivalent full-load hours (EFLH), considering only outdoor temperature, ranges widely, from 74 hours for Edmonton (in Alberta, Canada) to 883 hours for Chicago (in the US state of Illinois) (Figure 16) and 2,477 hours for Houston (Texas). District cooling supply reaches about 25 TWh yearly, for an EFLH of 1,390 hours. 


\section{Figure 16: Chicago District Cooling}

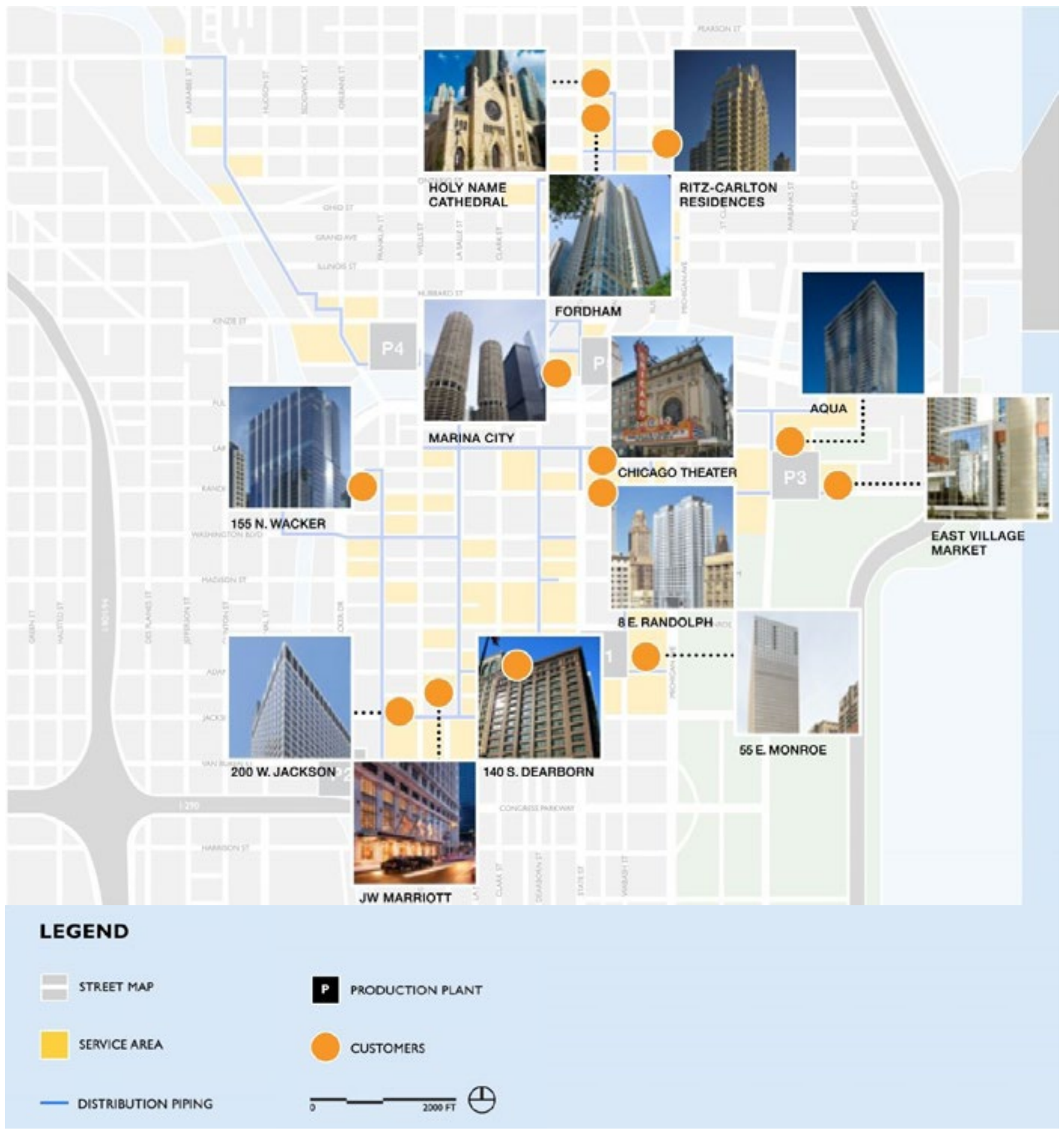

Source: Enwave Chicago.

Middle East. In the Middle East, all district energy is assumed to be district cooling. Installed district cooling capacity amounts to $14 \mathrm{GW}$. Assuming an average of 3,200 EFLH, not considering coincidence factors or occupancy rate, annual district cooling supply for the Middle East market reaches about $45 \mathrm{TWh}$. Figure 17 tracks the annual increase in district energy in the Middle East, and Figure 18 shows a picture of a typical district cooling plant in Qatar. 
Figure 17: Annual Increase in District Energy in the Middle East

District Energy Indusry Growth: Middle East

(sq meter customer bldg space connected/committed)

Aggregate reported 2006-2014 MM sq ft

$30,000,000$

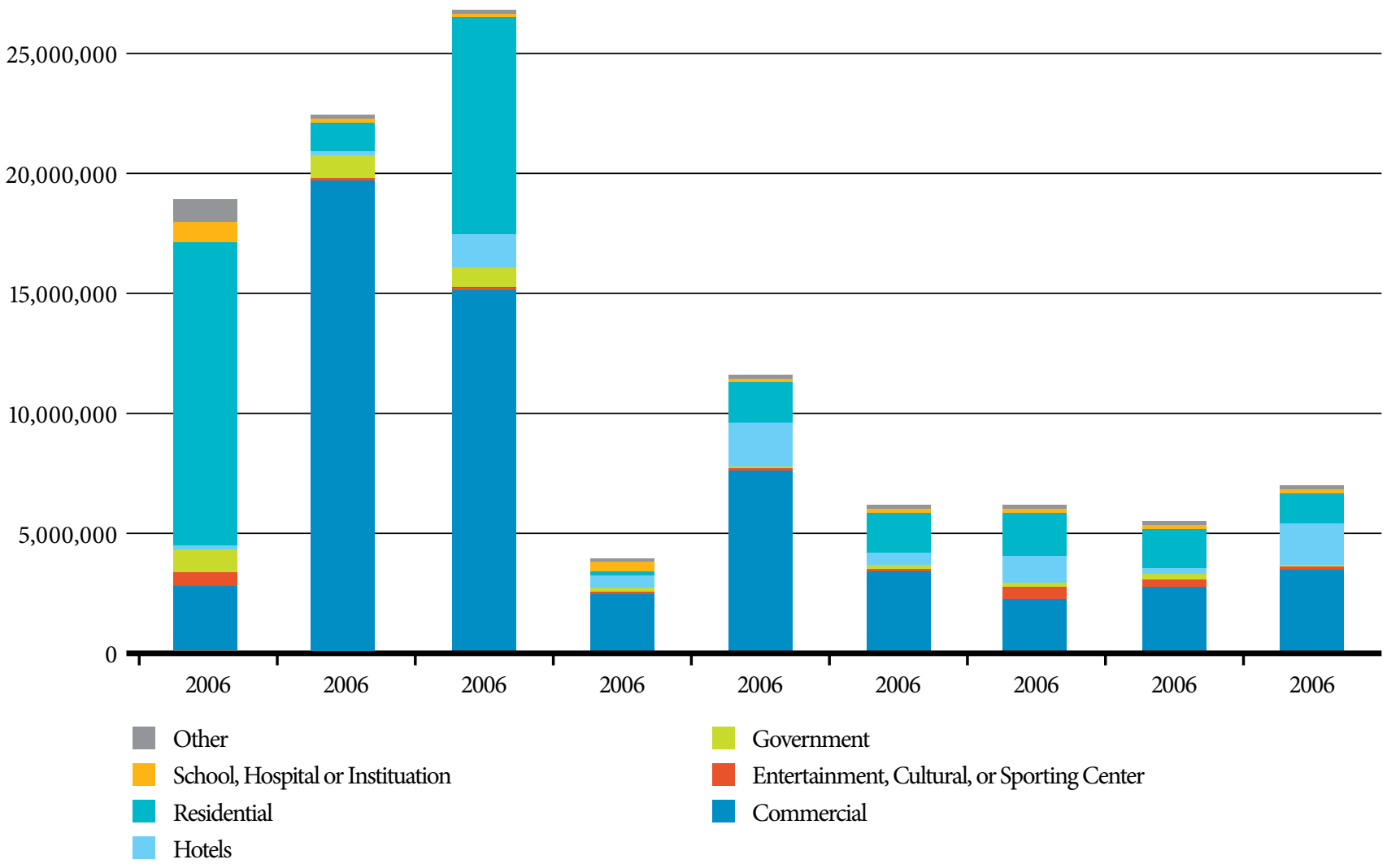

Source: IDEA (2008).

Figure 18: District Cooling Plant in Qatar

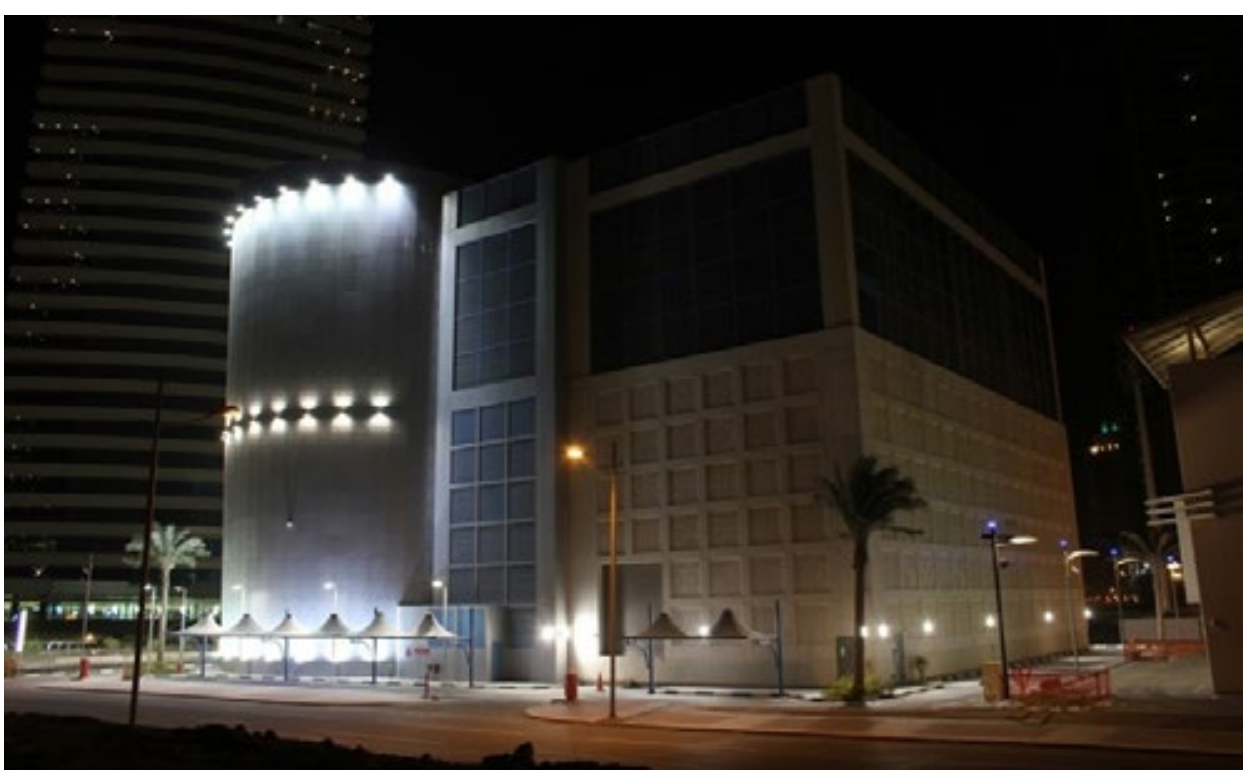

Source: Qatar Cool. 


\section{District Cooling Market in the PRC}

The PRC has a diverse climate, divided into five main zones: severe cold, cold, temperate, hot summer and cold winter, and hot summer and warm winter (Figure 19).

Figure 19: Climate Zones in the PRC

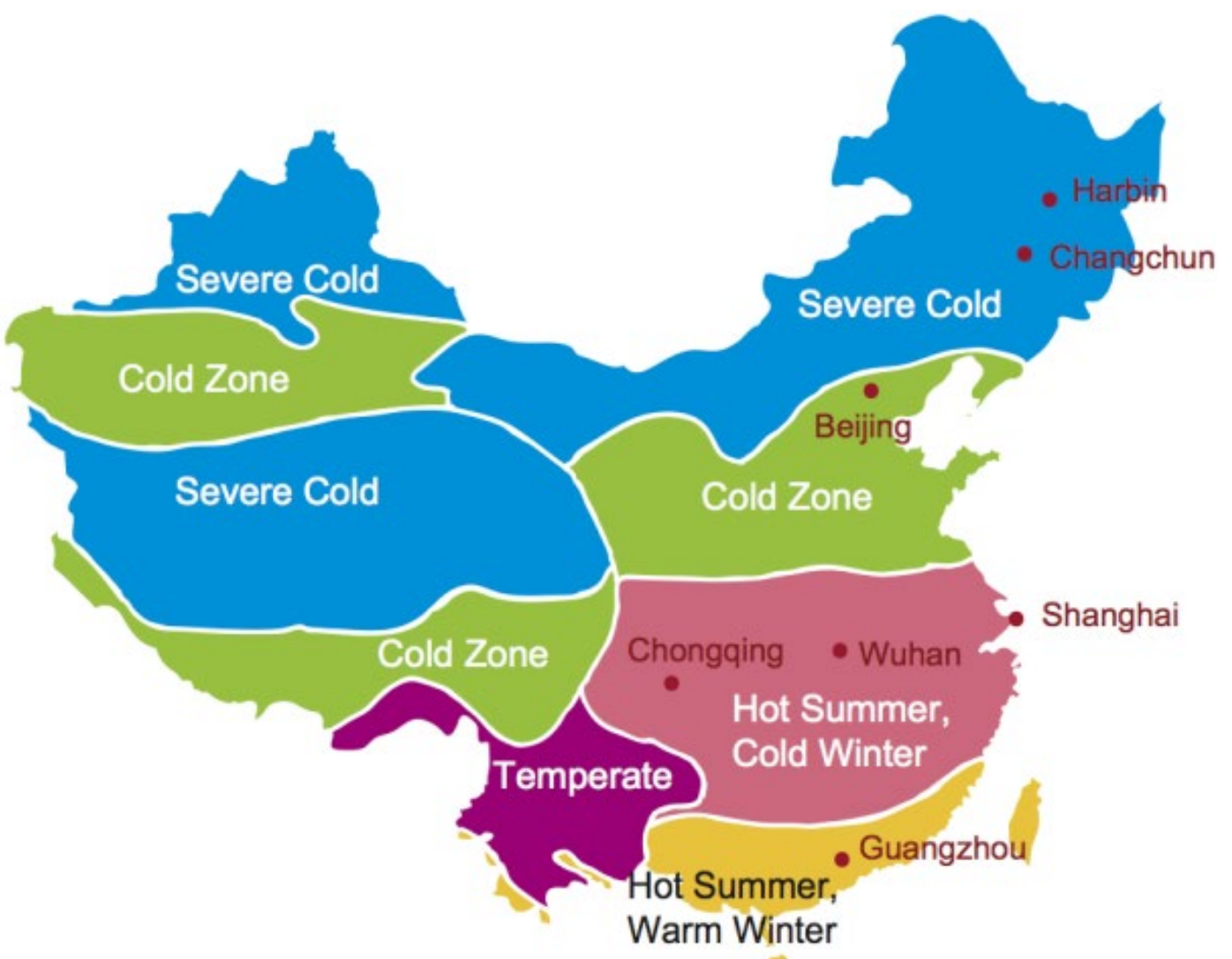

\begin{tabular}{lcc}
\hline \multirow{2}{*}{ Climate Zone } & \multicolumn{2}{c}{ Mean Monthly Temperature } \\
\cline { 2 - 3 } & Coldest & Hottest \\
\hline Severe cold & $\leq-10^{\circ} \mathrm{C}$ & $\leq 25^{\circ} \mathrm{C}$ \\
\hline Cold & $-10^{\circ} \mathrm{C}-0^{\circ} \mathrm{C}$ & $18^{\circ} \mathrm{C}-28^{\circ} \mathrm{C}$ \\
\hline Temperate & $0^{\circ} \mathrm{C}-13^{\circ} \mathrm{C}$ & $18^{\circ} \mathrm{C}-25^{\circ} \mathrm{C}$ \\
\hline Hot summer and cold winter & $0^{\circ}-10^{\circ} \mathrm{C}$ & $25^{\circ} \mathrm{C}-30^{\circ} \mathrm{C}$ \\
\hline Hot summer and warm winter & $>10^{\circ} \mathrm{C}$ & $25^{\circ} \mathrm{C}-29^{\circ} \mathrm{C}$ \\
\hline
\end{tabular}

Source: Berkeley Lab, University of California. 
The dimensioning indoor temperature for cooling in the PRC is $26^{\circ} \mathrm{C}$. In the severe cold and temperate climate zones, non-climate-related cooling loads, such as heat generated from appliances, humans, and machines, are the main drivers of cooling systems.

The study team found no official database with statistics showing the size of the PRC's district cooling market or any official source where district cooling projects in the PRC are listed. In the district heating sector, the government's China District Heating Association is active and provides such information; no corresponding association exists in the district cooling sector. However, several other associations, such as the China District Energy Association, which promotes the development of the PRC's district cooling market, have been established.

\section{A. History of District Cooling in the PRC}

While district heating had its start in the mid-20th century, district cooling in the PRC is a relatively new technology. It was developed early in the 21st century and gradually gained in popularity after the 11th Five-Year Plan (2006-2010), which pushed for conserving energy and reducing emissions, was launched.

In 2012-2013 the Government of the PRC called for more distributed energy projects-gas-fired combined heat and power (CHP) and CCHP plants, as well as solar photovoltaic projects-to reduce local emissions and the stress on the electricity transmission grid. As a result, district cooling started to be implemented on a larger scale as part of CCHP technology.

Unhindered by its relative newness, the district cooling sector in the PRC has drawn on experience in other district markets, including those in Japan, Europe, and North America. Today, there are district cooling systems in most tier 1 and tier 2 cities in the PRC (as defined in this report). The systems mainly cover commercial building complexes, specific development zones (or parks), and industries.

\section{B. Present District Cooling Market}

The size of the district cooling market in the PRC is hard to determine from the information gathered for this study. District cooling is unclearly defined and, as mentioned above, no database of statistics or information exists for the sector. But a number of projects were identified through interviews and a review of the literature; the best known, accounting for some $4.2 \mathrm{GW}$ of installed capacity, are listed in Appendix 3. The table gives key information about each project, such as project owner, cooling capacity, and technologies used.

Many of the project owners listed are dedicated local utilities established for specific projects. Other project owners are energy investors, general investors, public utility companies, and joint ventures between Chinese and foreign investors. Most district cooling project owners in the PRC are fully or partly owned by companies that were originally set up as state-owned enterprises.

The technologies used in the projects include heat-driven absorption chillers, electrical compressor chillers, and ice storage. The projects rely on different sources of energy, such as gas-fired CCHP plants, heat from CHP plants, and combined district heating and cooling systems. 
The potential district cooling market is discussed in section $\mathrm{X}$ (Future of District Cooling in the PRC).

\section{District Cooling Regulations}

The PRC has no specific regulations, policies, or government guidelines for district cooling, district heating, or distributed energy. The district cooling sector, where investors are likely to be interested only in feasible projects with good financial indicators, can be regarded as market driven. Pricing is based on competitive technologies, and the business environment is relatively clear, stable, and predictable for investors. Access to district cooling systems is therefore unregulated and unlimited.

To some extent, building energy codes in the PRC relate to district cooling. Overall energy efficiency is their main concern, and district cooling could be one of the measures adopted. The building energy codes can be classified into three categories:

Urban residential buildings 6

- Design Standard for Energy Efficiency of Residential Buildings in Severe Cold and Cold Zones (JGJ 26; 1995)

- Design Standard for Energy Efficiency of Residential Buildings in Hot Summer and Cold Winter Zone (JGJ 134; 2010)

- Design Standard for Energy Efficiency of Residential Buildings in Hot Summer and Warm Winter Zone (JGJ 95; 1995)

Rural residential buildings: Design Standard for Energy Efficiency of Rural Residential Buildings (GB 50824; 2012) 7

Commercial buildings: Design Standard for Energy Efficiency of Public Buildings (GB 50189; 2005) 8

The government of the PRC has passed laws to implement these building codes, and strives to improve compliance with building standards through follow-up and incentives.

\section{Players in the District Cooling Market}

Trade associations. These associations initiate and facilitate communication between stakeholders in the sector, provide technical support, submit proposals to relevant governmental bodies, publish articles, and promote academic communication internationally, among other functions. The associations most relevant to district cooling are:

- China District Energy Association (www.qyny.org)

- China Exploration \& Design Association, Construction and Equipment Engineering Branch (www.cnbef.com)

- Chinese Association of Refrigeration (www.car.org.cn)

- China Committee of Heating, Ventilation and Air-Conditioning (www.chinahvac.com.cn)

6 Global Buildings Performance Network. 2012. Building Energy Efficiency Policies in China. France. http://www.gbpn.org/sites/default/files/08.\%20China\%20Report_0.pdf 
Government bodies. Government bodies draft and implement national laws, regulations, policies, and standards, among other functions. The government bodies most relevant to the development of district cooling in the PRC are the following:

- National Energy Administration (www.nea.gov.cn)

- Ministry of Housing and Urban-Rural Development (www.mohurd.gov.cn)

- National Development and Reform Commission (www.ndrc.gov.cn)

- Various municipal bodies

The National Energy Administration could have a significant role in promoting the development of district cooling in the PRC. In the area of district energy, the Ministry of Housing and Urban-Rural Development is focused on district heating, rather than district cooling.

Various municipal bodies, such as district administrations, development zones, and technology parks, could provide the most significant government support for district cooling projects. Local administrations, empowered to influence local building design and land development criteria, and integrate energy planning into urban planning, can pave the way for district cooling.

Universities and research institutions. Educational and research institutions do research and development in the district cooling field, publish articles, and provide expertise in commercial and public panels, among other functions. The professors interviewed by the study team came from the following universities:

- Beijing University of Technology (Zhao Jiancheng), www.bjut.edu.cn

- Tsinghua University (Jiang Yi and Zhu Yingxin), www.tsinghua.edu.cn

- Tongji University (Long Weiding), www.tongji.edu.cn

- South China University of Technology (Hua Ben, for CCHP), www.scut.edu.cn

District cooling utilities. District cooling utilities in the PRC, like their counterparts worldwide, can be investors, asset managers, and operation and maintenance companies. Different types of companies, both domestic and international, are represented in the PRC's district cooling market.

The development of the energy service company (ESCO) model in recent years has increased the number of potential district cooling utility companies in the PRC that originate from equipment suppliers and contractors.

Design institutes. The design institutes plan and prepare project proposals, carry out feasibility studies, and design district cooling facilities. National, regional, and local design institutes originating from different business areas are involved in district cooling projects in the PRC. Design institutes include the following:

- Architectural design institutes

- Municipal engineering design institutes

- Electric power design institutes 
Publications. Many articles related to district cooling have been published in the PRC. For this report, the search engines Wanfan Data (万方数据) and China National Knowledge Infrastructure (中国知网) and the keyword “district cooling” (区域供冷) were used to gain access to those articles.

For 1985-2014, 352 articles, all published in academic journals, were found. The majority of the articles published in 1985-2001 pertained to district cooling technologies used in specific projects outside the PRC. The first article published in 2002 presented a specific district cooling project, Shanghai Pudong International Airport. Other articles after that discussed specific district cooling projects, including the Beijing Zhongguancun Western Region and Guangzhou University City projects. The project-specific articles dealt mainly with the overall concept of district cooling production and distribution, and with project construction and operation. Some articles also included technical and economic analyses, as well as operation and management principles and programs.

The various articles fell into one or more of the following subject categories:

- district cooling status;

- cooling demand;

- production technology;

- distribution technology;

- technical and economic analysis;

- environmental impact and benefits;

- operation and management; and

- international experiences.

The articles found during the study are sorted according to category and year of publication in a table in Appendix 2.

The articles most often dealt with production technology, technical and economic analysis, and district cooling status. Electric chillers, absorption chillers, water-source heat pumps and water-cooled chillers, and ice storage, were the most common production technologies described. Several articles went into combinations of electric chillers and ice storage systems, and the benefits of large differences in temperature between supply and return water $\left(\triangle \mathrm{T} \geq 8^{\circ} \mathrm{C}\right)$, such as reduced initial investment in the distribution network and lower energy consumption in the pump.

Articles describing the state of district cooling worldwide-from the earliest article found, a discussion of district cooling in Japan (Shen 1985) published in the International Journal of Refrigeration-generally presented district cooling as a mature technology worldwide with many cases of successful implementation in Europe and the United States. District cooling in the PRC, on the other hand, was repeatedly mentioned as a technology still in development and facing many challenges ahead. 
Several implemented projects in the PRC that were included in the articles gave good insight into lessons learned, and the potential for improvement, from project concept to commercial operation. Articles about the technical and economic analysis of district cooling systems described the low efficiency of implemented projects and the consequently high price of district cooling energy, similar to that of electricity (CNY0.8 per kilowatt-hour).

Whether district cooling systems are feasible at all and whether they are feasible in the hot summer and cold winter zone of the PRC or in its hot summer and warm winter zone, is the subject of ongoing debate. Relevant questions, both for and against district cooling, are being raised. The questions most often asked are:

- Does district cooling help save energy?

- Is the distribution network economically feasible?

- Do the load characteristics (load distribution and variations) meet the requirements of district cooling?

- Does district cooling help reduce emissions?

- Can free cooling and waste heat be used, and is such use feasible? 


\section{Future of District Cooling in the PRC}

As district cooling can be considered a value-added service, potential customers must be differentiated according to the importance they attach to its benefits. If the low price of household electricity and the relatively low appreciation of improved indoor climate compared with split-air type conditioning units among households are taken into account, residential buildings cannot be considered to be a target market for district cooling systems development in its early stages.

However, commercial buildings with a relatively stable cooling load and a predictable demand profile could be a priority building category for such development.

Figure 20: Building Floor Space in the PRC

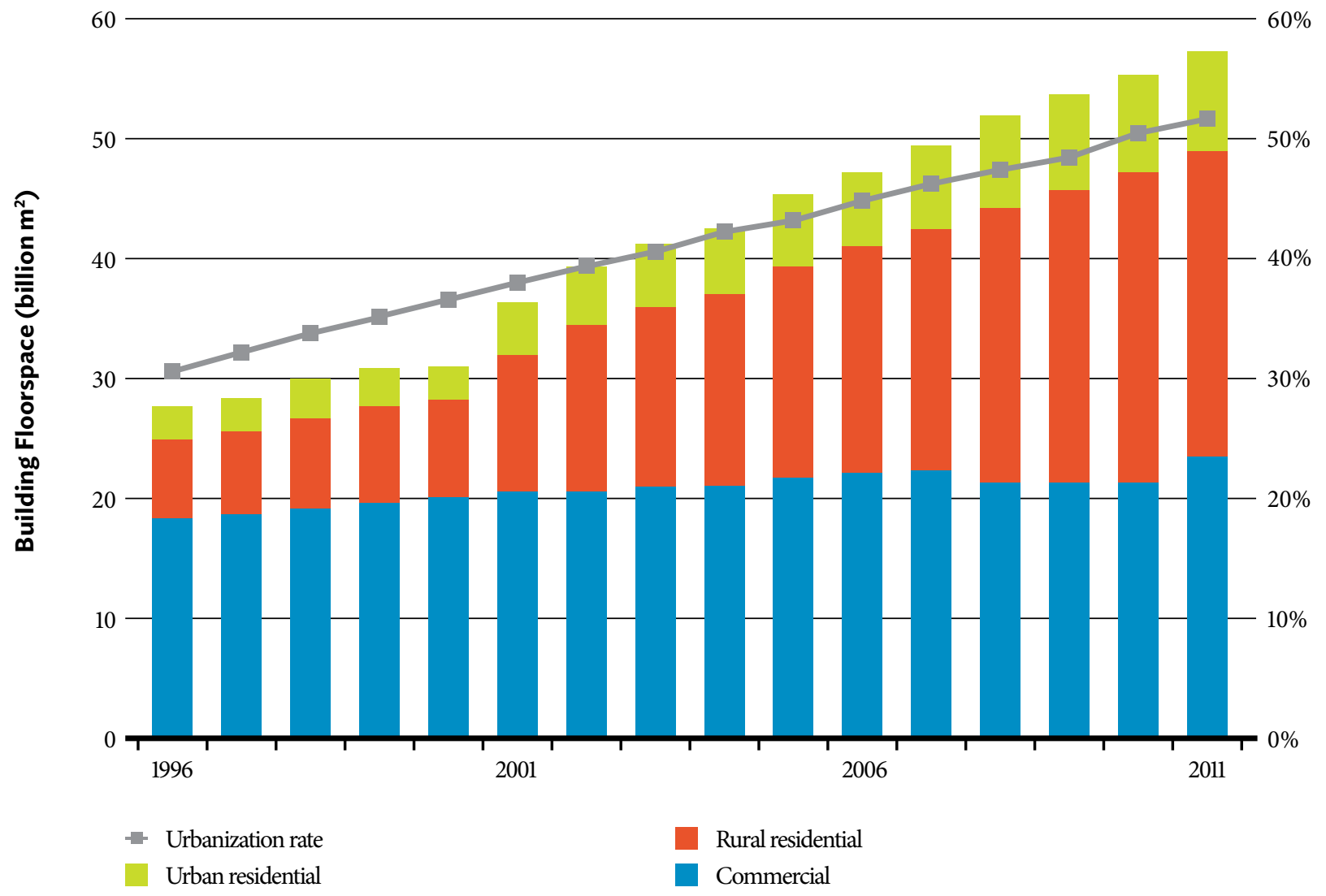


As shown in Figure 20, commercial building floor space in the PRC tripled in 2001-2011, increasing by 500 million $\mathrm{m}^{2}$ (or by about $11 \%$ ) yearly during the period. In 2011-2030, it is expected to double, and reach about 14 billion $\mathrm{m}^{2}$ by the end of the period (Figure 21). Growth, although somewhat slower, will still be relatively stable, at about 350 million $\mathrm{m}^{2}$ yearly.

Figure 21: Estimated Floor Space in the PRC by 2030

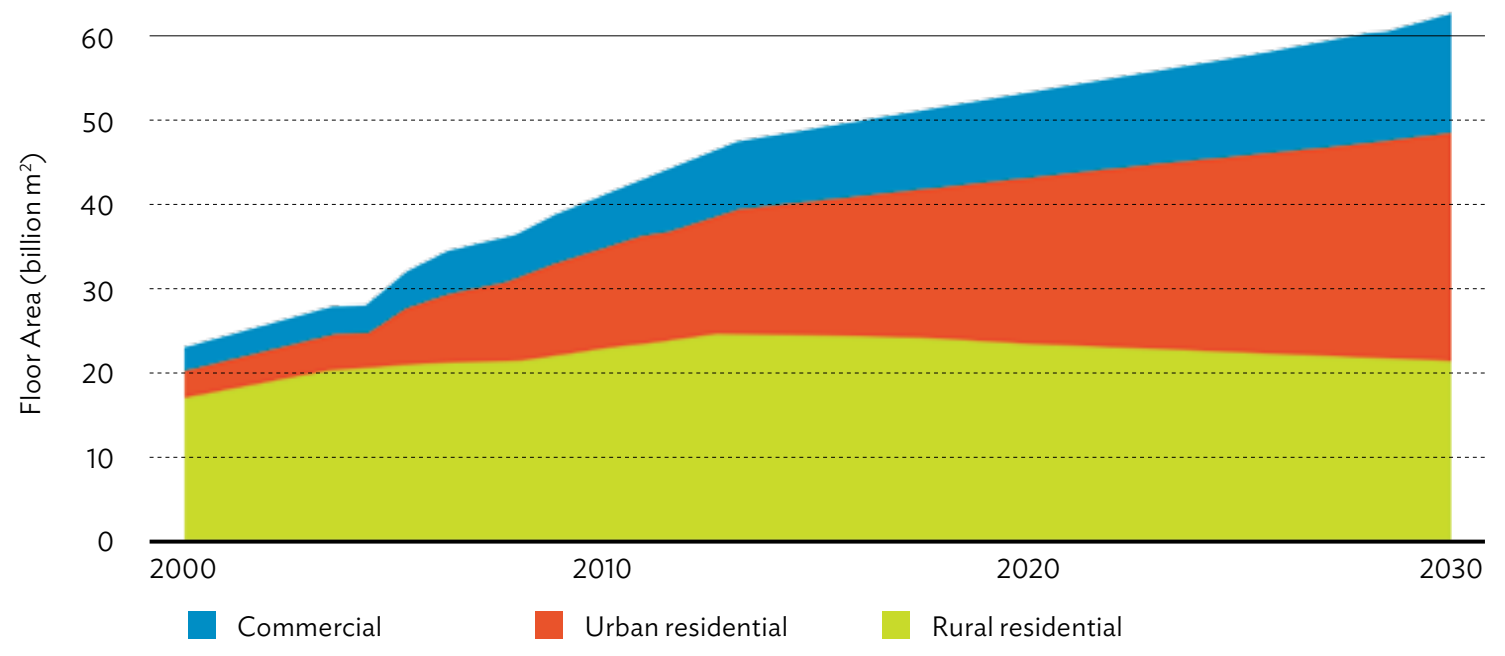

Source: Climate Policy Initiative.

Cooling demand in commercial buildings depends on several factors, such as building design, occupancy rate, and use, as well as local climate. The cooling index for commercial buildings in the PRC is typically $90-150$ watts $/ \mathrm{m}^{2}$. If an average cooling index of $110 \mathrm{watts} / \mathrm{m}^{2}$ is assumed, cooling demand in commercial buildings should increase by 38.5 terawatts yearly from 2010. In Europe, as described in section VIII, district cooling covers $1.0 \%$ of the total market and $0.2 \%$ of the potential market. To quantify the PRC's annual cooling ptential, further assumptions will have to be made. Using $0.01 \%$ of all commercial buildings as basis for district cooling (several buildings can be connected to the same cooling system) would result in an annual district cooling load of 3,850 MW. Climate variation causes the EFLH in the PRC to vary quite significantly (see North America subsection in section VIII), between about 900 hours and 2,500 hours. On the conservative assumption that EFLH will total 1,400 hours, the 3,850 MW annual cooling demand would correspond to 5.39 TWh.

District cooling of airports, data centers, hospitals, industries, and other buildings with high-density cooling demand would also be feasible.

The potential annual increase in demand for district cooling in the PRC of 5.39 TWh should be compared with the total cooling demand in the markets described in section VIII-3.5 TWh in Japan, 3 TWh in Europe, 25 TWh in North America, and $45 \mathrm{TWh}$ in the Middle East.

The available data on cooling demand for the projects listed in Appendix 3 can be summed up as follows. The installed capacity of over $4.2 \mathrm{GW}$ corresponds to some 5.9 TWh (assuming a conservative average EFLH of 1,400 hours). This means that the PRC's district cooling market at present (based on the projects mentioned in Appendix 3 alone) is larger than the Japanese and European markets, and has the potential to reach the level of the North American market within 5 years. 


\section{Conclusions and Recommendations}

District cooling is a feasible energy system in the PRC and has huge market potential. Unlike traditional air-conditioning systems, district cooling uses different resources (including renewable energies) that can improve energy efficiency and indoor climate significantly, and should therefore be promoted further in the PRC.

The PRC's district cooling market at present ( $>5.9 \mathrm{TWh})$ is larger than both the Japanese (3.5 TWh) and European ( $3 \mathrm{TWh}$ ) markets, and could reach the level of North America ( $25 \mathrm{TWh}$ ) within 5 years if it grows by up to $5.39 \mathrm{TWh}$ yearly as projected.

Below are a few key findings from the study, which have been sorted through an analysis of strengths, weaknesses, opportunities, and threats (SWOT) to give an overview of the business environment for district cooling in the PRC.

Strengths

- $25 \%-50 \%$ increase in energy efficiency

- improved environmental efficiency

- long life span of up to 50 years, leading to lower maintenance cost and better management

- financial competitiveness (given the right preconditions) compared with traditional split air conditioners

Weaknesses

- high initial costs (front-loaded investments)

- financially competitive only for areas with relatively high energy density

- lack of incentives and regulations

- need for well-structured and coordinated planning, design, and project implementation

Opportunities

- huge market growth potential of $5.39 \mathrm{TWh}$ or $4.2 \mathrm{GW}$ yearly, larger than the current Japanese district cooling market as well as the European market

- greater environmental awareness among the general public and within government

- increased public expectations of comfort

- $\quad$ success stories 
Threats

- consumer protection measures related to pricing and quality of services

- unsatisfactory feasibility studies

- delayed load buildup and high processor occupancy

- inexperienced project planners, designers, and implementers

Despite being well known in the PRC, the concept of district cooling is variously defined and the definitions do not always include centralized cooling systems.

District cooling in the PRC has also not developed according to international best practice, according to the discussion in section III and statements made by those interviewed (Appendix 1). Several centralized cooling systems that fit the definition of district cooling in this report have been successfully implemented in the PRC and could serve as good examples of implemented projects. But other projects have been unsuccessful (to some extent). Energy efficiency has been relatively low and cooling rates have been high. Part of the reason is the unsatisfactory planning and design basis, resulting in oversized and expensive systems with low utilization ratio and unsatisfactory implementation, and therefore in high operation and maintenance costs. These projects have set an unfortunate precedent for future district cooling projects, and bred skepticism toward district cooling as a whole.

Improvements need to be made along the project value chain, from the initial evaluation of potential projects to design and implementation. International district cooling best practice technology is available on the PRC market, so it is mainly increased attention, through the publication of a district cooling handbook and the implementation of demonstration projects, that is required.

For the development of new district cooling systems, priority should be given to tier 1 and tier 2 cities with new construction projects and commercial blocks, possibly in the central business district. Areas with high-density cooling demand, such as industrial development zones, airports, and hospitals, could also be a good basis for development.

Many things could be learned from the China District Heating Association, which administers the PRC's district heating market, in raising awareness of district cooling, following up implemented projects, and forecasting potential. A corresponding function could be developed for district cooling.

The following measures are suggested for the further promotion of district cooling in the PRC:

- Assign to the China District Heating Association the role of national coordinator for district cooling, similar to the role taken on by the International District Energy Association and the Swedish District Heating Association in both district heating and cooling.

- Develop a screening tool with benchmark values for identifying feasible district cooling projects.

- Produce a best-practice handbook for district cooling in the PRC, covering the entire project value chain.

- Identify a district cooling pilot project to serve as demonstration project for international district cooling best practice. 
Technical assistance would facilitate the implementation of some of the foregoing items. Technical assistance would be needed to support the China District Heating Association to institutionalize district cooling in its present operation. The following work, for example, could be done under technical assistance:

- Upgrade the existing magazine published by the association to include a chapter specifically on district cooling.

- Upgrade the existing website of the association to include a district cooling section.

- Identify district cooling operators in the PRC.

- Upgrade the existing statistical database of the association to include district cooling, or establish a new database.

- Publish the best-practice handbook for district cooling in the PRC. 


\section{Appendix 1}

\section{Interview Results}

\begin{tabular}{ll}
\hline Interviewee & $\begin{array}{l}\text { Jiang Yi } \\
\text { Professor of Tsinghua University } \\
\text { Doctoral Supervisor } \\
\text { Academician of Chinese Academy of Engineering } \\
\text { Other participants: Several students of Professor Jiang Yi }\end{array}$ \\
\hline Interviewers & $\begin{array}{l}\text { Mikael Jakobsson } \\
\text { Lin Ling }\end{array}$ \\
\hline Time and date & 16 September 2015 \\
\hline Venue & Tsinghua University \\
\hline Initial questions & Answers (interpretation/shortened on the basis of discussions) \\
\hline
\end{tabular}

1. How is district cooling defined

A district cooling system shall have different customers for different buildings; otherwise, it should be considered as centralized cooling.

in the People's Republic of

China (PRC)?

Area and capacity are not important with regard to the definition of district cooling.

2. Is district cooling feasible in the PRC?
As shown so far, no.

It has been shown to be too expensive in terms of both investment and operation costs.

(Professor Jiang Yi explains by presenting several project examples.)

\section{Are there any statistics with regard to the district cooling market in the PRC?}

No, there are no such statistics available.
4. What are the most common (and most feasible) applications?
Office buildings, shopping malls, etc.-in general, facilities where the cooling load is predictable and relatively stable.
5. Are there any supporting laws, policies, and guidelines?
No, not really. However, some developers are including district cooling requirements in their criteria systems.
General comments from the interviewees:
The district heating market has been developing for over 50 years. Even though the district heating market is regulated, there are still huge challenges with regard to global efficiency, comfort levels, and economic feasibility. If that is taken into consideration, how could district cooling, which is relatively immature, be readily feasible?

There is a need for a more comprehensive evaluation of district cooling systems; looking into global efficiency, total investment costs, and total operating costs. 


\begin{tabular}{ll}
\hline Interviewee & $\begin{array}{l}\text { Xu Wenfa } \\
\text { Chair of China District Energy Association } \\
\text { Chair of China District Energy Industry Alliance } \\
\text { Editor of District Energy magazine }\end{array}$ \\
\hline Interviewers & $\begin{array}{l}\text { Mikael Jakobsson } \\
\text { Lin Ling } \\
\text { Liu Xidi }\end{array}$ \\
\hline Time and date & 24 September 2015 \\
\hline Venue & Fanhua Group \\
\hline Initial questions & Answers (interpretation/shortened on the basis of discussions) \\
\hline
\end{tabular}

1. How is district cooling defined

A district cooling system consists of a centralized production station and a distribution in the People's Republic of China (PRC)? network, and supplies cooling to several buildings.

2. Is district cooling feasible in the PRC?

\section{Absolutely!}

There have been arguments over the feasibility of some projects, but the quality of project implementation is improving and the technology is more developed.

Technologies such as thermal energy storage are improving the feasibility even more.

\section{Are there any statistics with regard to the district cooling market in the PRC?}

No, there are no such statistics available.

\section{What are the most common (and most feasible) applications?}

Airports, hospitals, commercial buildings, etc.

\section{Are there any supporting laws, No, not really. policies, and guidelines? \\ No, not really.}




\section{Zhao Jiancheng}

Interviewee

General Manager of Beijing Imux District Cooling Technology Development Company Professor of Beijing University of Technology

$\begin{array}{ll} & \text { Lin Ling } \\ \text { Interviewers } & \text { Tan Lei }\end{array}$

\begin{tabular}{ll}
\hline Time and date & 29 September 2015 \\
\hline Venue & Imux District Cooling Technology Company \\
\hline Initial questions & Answers (interpretation/shortened on the basis of discussions) \\
\hline $\begin{array}{l}\text { 1. How is district cooling defined } \\
\text { in the People's Republic of } \\
\text { China (PRC)? }\end{array}$ & $\begin{array}{l}\text { A district cooling system has not been exactly defined. The main characteristic of a } \\
\text { end users, such as airports and commercial complex buildings. }\end{array}$ \\
& $\begin{array}{l}\text { For an exact definition, one may refer to the definition given by the International District } \\
\text { Energy Association. }\end{array}$
\end{tabular}

It is feasible only under proper conditions.

For example, the Zhongguancun West Region project has been in operation for 10 years, 2. Is district cooling feasible in the managed by our company. We have accumulated a lot of experience in district cooling. PRC? A large expense in this district cooling project is the distribution network, which takes up almost one-sixth of the total investment. (The cooling pipes are laid in a tunnel.)

3. Are there any specific concession laws for district cooling in the PRC?
There is no specific concession law on the Zhongguancun West Region project. The price of cooling water was negotiated between the project operator and the end users.
4. Who are the stakeholders in different phases of a district cooling project?

5. Are there any supporting laws, policies, and guidelines?

6. What is the most common business model for district cooling projects?
At present, government involvement in the district cooling market is a given. Of course, the district cooling market decisions are still based on market demand.
For an installation project, if power consumption during peak hours can be permanently reduced, for example, by moving to valley time through the use of thermal storage technology, then a government subsidy of CNY500 per kilowatt is awarded by the Beijing government.

In Shenzhen, the government offers an ice storage electric price of CNY0.28 per kilowatt-hour.
Now district cooling charges take the following forms: charging by building area, charging by cold water flow, or charging through a combination of forms (basic charge, network connection fee, etc.)

Some projects have private investors. For such kinds of district cooling projects, the price is normally decided upon negotiation with the end users.
7. What aspect do we need to pay attention to regarding the application of district cooling technology?

\section{Three points need attention:}

- confirming whether the users accept district cooling;

- evaluating the overall technical safety and economic viability of a project; and

- carrying out the project very carefully and with a lot of planning. 


\section{Wang Zhao}

Deputy Chief Engineer and Senior Engineer of Architectural Design

Interviewee

\& Research Institute

South China University of Technology

Deputy Director of Chinese Regional Energy Committee

Deputy Director of Green Building Association

$\begin{array}{ll} & \text { Mikael Jakobsson } \\ \text { Interviewers } & \text { Lin Ling } \\ & \text { Cheng Jie }\end{array}$

\begin{tabular}{ll}
\hline Time and date & 14 October 2015 \\
\hline Venue & Architectural Design \& Research Institute, South China University of Technology \\
\hline Initial questions & Answers (interpretation/shortened on the basis of discussions) \\
\hline
\end{tabular}

1. How is district cooling defined in the PRC?
Purely from a technical perspective, a district cooling system is a production plant providing cooling water to a number of buildings. However, "district cooling" is already regarded as a form of energy investment. Cooling water is sold as a commodity. So "district cooling" is defined more as an investment pattern.

Personal opinion: District cooling should be defined as a business model where the chilled water/cooling is sold as a commercial product. If the supplier and the user are the same entity, then it is not a district cooling project, but just another way of supplying energy.

Yes.

- The fast urbanization in the PRC offers plenty of potential for developing district cooling projects within newly developed areas. Construction in cities is increasing in scale and extent. This provides favorable conditions for the implementation of district cooling projects.

- Traditionally, utility management by the end users themselves is rather inefficient; hence, in the near future, users would tend to prefer the higher-quality services provided by a professional energy supplier (a third-party service by the district cooling management).

- Considering the fact that a concession is always engaged in district cooling projects, it would be an attractive market for investors, especially if it is a monopoly market.

- The technical challenges have been mostly overcome in the past 10 years. However, the unclear interface among the design, construction, and operation stages of an engineering project still makes such projects considerably challenging.

- Despite the aforementioned positive factors, district cooling projects would still require thorough consideration during project development, especially with regard to economic performance.
3. Who are the stakeholders in different phases of a district cooling project?
In addition to the investors, the government also plays a key role in district cooling projects. Government can be involved in the investment itself or provide free land for the energy station.
4. What are the critical factors for success in a district cooling project?
- The government must change its form of participation, from supervising/subsidizing to investing/supplementing (in the distribution network, land, etc.).

- The economic analysis for each project is crucial in project development. It is very important to define the project boundaries and evaluate the risks from the start. We don't believe in district cooling for residential buildings for now. 


\begin{tabular}{ll}
\hline Interviewee & $\begin{array}{l}\text { Yin Ping } \\
\text { President of Guangdong Gold Science \& Technology Development Co. } \\
\text { President of Nanjing Greensmile Science \& Technology Development Co. } \\
\text { Professor of Hunan University }\end{array}$ \\
\hline Interviewers & $\begin{array}{l}\text { Mikael Jakobsson } \\
\text { Lin Ling } \\
\text { Cheng Jie }\end{array}$ \\
\hline Time and date & 14 October 2015 \\
\hline Venue & Guangdong Gold Science \& Technology Development Co. \\
\hline Initial questions & Answers (interpretation/shortened on the basis of discussions)
\end{tabular}

1. How is district cooling defined in the PRC?
A district cooling system is a centralized energy station set among a group of buildings within a defined region and providing chilled water in order to supply cooling capacity and fulfill the cooling demand via the cooling water network. A cooling source system consists of one or several energy stations.
2. Is district cooling feasible in the PRC?
Yes.

The factors promoting the development of district cooling projects in the PRC are:

- strong support from the government;

- rapid economic development and high living standards;

- need for environmental protection;

- projected establishment of a domestic carbon trading market in the PRC in 2017; and

- gas supply in excess of domestic demand and, hence, a lower price for gas
3. Are there any specific concession laws for district cooling in the PRC?
There is no specific concession law for district cooling. There is an overall national law for concessions, which is currently applied in district cooling projects as well. The price is to be negotiated between the suppliers and the users.
4. Who are the stakeholders in different phases of a district cooling project?
Investors and contractors:

The five major state-owned power enterprises are the main players. Some district cooling projects are combined with gas-fired combined cooling, heating, and power systems. Source of capital are bank loans from China Development Bank $(80 \%)$ and self-raised funds (20\%).

There is local public-private (local government, Sino-foreign joint ventures, etc.) cooperation as well, especially when river water/groundwater/ seawater heat pumps are involved, or industrial surplus heat is used.

A number of public companies and private enterprises have also invested in combined cooling, heating, and power plant projects.
5. Are there any supporting laws, policies, and guidelines?
Not specifically for district cooling. When it comes to using industrial surplus heat for district energy (heating and cooling), yes. 
6. What is the most common business model for district cooling projects?
The current district cooling projects mostly overlap with distributed energy projects (gas-fired small trigeneration units), promoted by the investors/suppliers within the energy business. Local municipalities could also participate as investors in some projects.
7. What are the key economic factors for the success of a district cooling project? General comments from the interviewee:
Some key economic indicators need to be considered:

- energy load density, including ramp-up of energy load, density, and simultaneity factor (load density and the usage coefficient can reflect the characteristics of the energy supply-for example, the usage coefficient of residential buildings is low);

- sale price of cooling (considering the difference with or without connection fee);

- electricity price;

- gas price (with or without subsidies);

- price of land for the energy station (since this price is very high in some large cities, e.g., Beijing or Shanghai, in the economic analysis of a district cooling system, a reduction in land area used is important)

- content of "connection fee" (boundary of investment in distribution network, a charge that differs between regions and is called "infrastructure use fee" or "connection fee"; in essence, users are asked to bear a portion of the initial investment cost);

- cooling hours (the longer the cooling time, the more favorable the prospects for a project); and

- cooling supply distance (scale of distribution network).
General comments from the interviewees:
Pure district cooling projects are very few, often because of poor economic performance.

Combining district cooling projects with gas-fired distributed energy projects (trigeneration projects) is a growing trend.

It is not a good idea to use district cooling in residential areas because of the complexity of consumer behavior. Its use is limited to commercial applications, at least until the near future. 


\section{Long Weiding}

Professor, Sino-German College of Applied Sciences, Tongji University

Interviewee

Executive Director, China Committee of HVAC

Ex. Head of E Section (Air Conditioning \& Heat Pump),

International Institute of Refrigeration

Deputy Director, Sino-UK Institute of Sustainability, Tongji University

Mikael Jakobsson

Lin Ling

Cheng Jie

\begin{tabular}{ll}
\hline Time and date & 14 October 2015 \\
\hline Venue & A hotel in Shanghai \\
\hline Initial questions & Answers (interpretation/shortened on the basis of discussions) \\
\hline
\end{tabular}

1. How is district cooling defined in the PRC?

The district cooling system should not only be a centralized production plant providing chilled water to multiple end users, but could also be multiple distributed plants integrated into one network for pooled operation.

2. Is District Cooling feasible in

Yes. However some risks, such as the occupancy rates in the supply area, and the period for ramp-up of energy load should be taken into consideration. For example, one project was constructed to the full cooling demand but implemented in stages as cooling load connections to customers were completed. This led to a large one-time investment and resulted in poor economic benefits.

3. Are there any supporting laws,

The government has issued policies to encourage the application of natural gas and policies and guidelines? renewable energy sources in distributed energy projects. General comments from the
interviewee:
The district cooling system has development potential. But there is a need for more comprehensive evaluation before implementing projects. 


\begin{tabular}{|c|c|}
\hline Interviewee & $\begin{array}{l}\text { Zhu Yingxin } \\
\text { Professor, Tsinghua University } \\
\text { Vice Dean, Head of Department of Building Science }\end{array}$ \\
\hline Interviewers & $\begin{array}{l}\text { Mikael Jakobsson } \\
\text { Lin Ling } \\
\text { Liu Xidi }\end{array}$ \\
\hline Time and date & 27 October 2015 \\
\hline Venue & Tsinghua University \\
\hline Initial questions & Answers (interpretation/shortened on the basis of discussions) \\
\hline $\begin{array}{l}\text { 1. How is district cooling defined } \\
\text { in the PRC? }\end{array}$ & $\begin{array}{l}\text { In the PRC, many centralized cooling projects are also called district cooling systems. This } \\
\text { means that the construction projects have the same owners and functions. }\end{array}$ \\
\hline $\begin{array}{l}\text { 2. Is district cooling feasible in the } \\
\text { PRC? }\end{array}$ & $\begin{array}{l}\text { - Not really. } \\
\text { - Whether it is a centralized cooling system or a district cooling system, its success } \\
\text { projects have failed because of the high cost of electricity or because of a huge } \\
\text { - Many detailed aspects have to be seriously considered during the planning of a } \\
\text { district project. Some preconditions have to be met. } \\
\text { - Density of cooling demand should be high. } \\
\text { - Plot ratio should be high. } \\
\text { - User behavior should be consistent. } \\
\text { - Phe project should not require long-distance transmission. } \\
\text { - Before anything is done, a thorough study of the project condition, combined with } \\
\text { optimized conceptualization and design, is the most important starting point of a } \\
\text { - Theject. } \\
\text { chosen. }\end{array}$ \\
\hline
\end{tabular}

A really reliable and sustainable project should be the natural choice from the market. The market should decide what is the most economical and energy-saving technology. A good

General comments from the interviewee: Government can also play an important role in the market by refraining from action. For
example, it should not promote ground-source heat pumps. 
Appendix 2

\section{District Cooling Papers and Articles Published, 1985-2014}

\begin{tabular}{|c|c|c|c|c|c|c|c|c|c|}
\hline Year & $\begin{array}{l}\text { District } \\
\text { Cooling } \\
\text { Status }\end{array}$ & $\begin{array}{l}\text { Cooling } \\
\text { Demand }\end{array}$ & $\begin{array}{l}\text { Production } \\
\text { Technology }\end{array}$ & $\begin{array}{l}\text { Distribution } \\
\text { Technology }\end{array}$ & $\begin{array}{l}\text { Technical and } \\
\text { Economic } \\
\text { Analysis }\end{array}$ & $\begin{array}{l}\text { Environmental } \\
\text { Impact and } \\
\text { Benefits }\end{array}$ & $\begin{array}{c}\text { Operation } \\
\text { and } \\
\text { Management }\end{array}$ & $\begin{array}{c}\text { Introduction } \\
\text { of Foreign } \\
\text { Experiences }\end{array}$ & Total \\
\hline 1985 & & & & & & & & 1 & 1 \\
\hline 1986 & & & & & & & & 1 & 1 \\
\hline 1987 & & & & & & & & 1 & 1 \\
\hline 1990 & & & & 1 & & & & & 1 \\
\hline 1992 & & & & & & & & 1 & 1 \\
\hline 1995 & & & & & & & & 1 & 1 \\
\hline 1996 & & & & & & & & 1 & 1 \\
\hline 1997 & & 1 & 1 & 1 & & & & 1 & 4 \\
\hline 1998 & 3 & & 1 & & & & & 1 & 5 \\
\hline 1999 & 2 & & 1 & & 1 & & & & 4 \\
\hline 2000 & & & & & & 1 & & 1 & 2 \\
\hline 2001 & & & 1 & 3 & 1 & & & 1 & 6 \\
\hline 2002 & & & 1 & & 4 & & & & 5 \\
\hline 2003 & 3 & & 5 & 2 & 3 & & & 1 & 14 \\
\hline 2004 & 3 & 1 & 7 & 3 & 1 & & & 3 & 18 \\
\hline 2005 & 6 & 2 & 3 & 1 & 6 & & 2 & 1 & 21 \\
\hline 2006 & 5 & 1 & 7 & 3 & 2 & 1 & 6 & 1 & 26 \\
\hline 2007 & 4 & & 9 & 3 & 14 & 2 & 3 & & 35 \\
\hline 2008 & 6 & 1 & 4 & 3 & 6 & 1 & 5 & 2 & 28 \\
\hline 2009 & 9 & 1 & 9 & 3 & 4 & 2 & 1 & & 29 \\
\hline 2010 & 7 & 3 & 16 & 2 & 3 & & 2 & 1 & 34 \\
\hline 2011 & 5 & & 8 & 1 & 8 & 3 & 4 & & 29 \\
\hline 2012 & 5 & 1 & 3 & 3 & 7 & 2 & 7 & & 28 \\
\hline 2013 & 4 & 2 & 4 & 2 & 8 & 2 & 3 & & 25 \\
\hline 2014 & 2 & 3 & 9 & 4 & 9 & 5 & & & 32 \\
\hline Total & 64 & 16 & 89 & 35 & 77 & 19 & 33 & 19 & 352 \\
\hline
\end{tabular}

Sources: Wanfang Data search engine and China National Knowledge Infrastructure search engine. 


\title{
Appendix 3
}

\section{Implemented and Ongoing Projects}

Project Name
Project Overview
Completion Status

(Liu et al. 2005;

Dong 2011)

\author{
Project owner: Shanghai International Airport Co., Ltd. \\ Type of owner: $\quad$ SOE \\ Total cooling load: $82.8+87.2=170 \mathrm{MW}$ \\ Total cooling area: 0.59 million $\mathrm{m}^{2}+0.48$ million $\mathrm{m}^{2}$ \\ Overall technology: CCHP \\ Cooling technology: Electric compressor chillers and \\ absorption chillers
}

Beijing

Zhongguancun

West Region

(Song 2004; Zhao

and Niu 2004)
Project owner:

Type of owner:

Total cooling load: $42.2 \mathrm{MW}$

Total cooling area: 0.37 million $\mathrm{m}^{2}$

Overall technology: Pure district cooling

Cooling technology: Electric compressor chillers

and ice storage

Temperatures: $\quad 1.1^{\circ} / 12.2^{\circ}$ (supply/return)
Beijing Imux District Cooling

Technology Development Co., Ltd.

\section{Guangzhou}

University City

(first-stage building

area: 3.52 million $\mathrm{m}^{2}$ )

(Wu et al. 2010; Fu

and $\mathrm{Wu} 2011 ; \mathrm{Tan}$

2009; Qiu 2007)
Project owner: Guangzhou University Town Energy

Co. Ltd, Guangzhou University

Town Huadian New Energy Co.,Ltd.

Type of owner: Local utility company

Total cooling load: $28.8+203.9+88+120.6=441 \mathrm{MW}$

Total cooling area: N/A

Overall technology: Pure cooling

Cooling technology: Electric compressor chillers, absorption chillers, and ice storage

Temperatures: $\quad 2^{\circ} / 13^{\circ}$ (supply/return)
The

first-stage project was completed Implemented in 2004; the secondstage project, in 2005.
Some office buildings in Haikou City (Song et al. 2010) $\begin{array}{ll}\text { Project owner: } & \text { N/A } \\ \text { Type of owner: } & \text { N/A }\end{array}$

Total cooling load: $23.83 \mathrm{MW}$

Total cooling area: 0.295 million $\mathrm{m}^{2}$

Overall technology: Pure cooling

Cooling technology: Electric chillers (15.15 MW) combined with ice storage

Temperature: $3.3^{\circ} / 13.3^{\circ}$ (supply/return)
Uunclear

2010
Sanya Yalongwan (Song et al. 2010; Sun et al. 2012)
Project owner: Huade Pengye Energy Investment

$$
\text { Co., Ltd. }
$$

Type of owner: Energy investor

Total cooling load: $31.24 \mathrm{MW}$

Total cooling area: 0.36 million $\mathrm{m}^{2}$

Overall technology:Pure cooling

Cooling technology: Electric chillers (23.7 MW) combined with ice storage

Temperature: $\quad 3.3^{\circ} / 11^{\circ}$ (supply/return)
The first-stage project (8 of 11 hotels)

has been implemented. 
Guangzhou Zhujiang New City (Yin 2013)
Project owner: Guangzhou Zhujiang New City Energy

$$
\text { Co., Ltd }
$$

Type of owner: Sino-foreign JV

Total cooling load: $105 \mathrm{MW}$

Total cooling area: 1 million $\mathrm{m}^{2}$

Overall technology: Pure cooling

Implemented

2010

Cooling technology: Electric chillers (23.7 MW)

combined with ice storage

Temperature: $\quad$ N/A N/A

\section{Zhuhai Hengqin}

Island

(Yin 2013)
Project owner: Zhuhai Hengqin Energy Co., Ltd

Type of owner: Local utility company

Total cooling load: $911 \mathrm{MW}$

Total cooling area: 15 million $\mathrm{m}^{2}$

Overall technology: CCHP

Cooling technology: Absorption chiller, electric chiller, and ice storage

Temperature: $\quad 5^{\circ}$ (supply)
The firststage project has been

implemented. al. 2010; Ma et al. 2011)

\author{
Project owner: $\quad$ Nanjing Fasike Energy Co., Ltd \\ Type of owner: Local utility company \\ Total cooling area: 2.31 million $\mathrm{m}^{2}$ \\ Overall technology:DHCS \\ Cooling technology: River-source heat pump/chiller \\ and ice storage \\ Temperature: $\quad 4^{\circ} / 12^{\circ}$ (supply/return)
}

Centre

(Yin 2013)
Total cooling area: 0.78 million $\mathrm{m}^{2}$ New Energy Technology Co., Ltd.

Project owner: Tianjin Jiayuan Xingchuang Local utility company

Overall technology:DHCS

Cooling technology: Ground-source heat pump/chiller combined with ice storage

Temperature: $\quad 4^{\circ} / 12^{\circ}$ (supply/return)

\section{Shanghai}

Caohejing Modern

Service Industry

Aggregation

(Gu et al. 2011; Gao

et al. 2010)
Project owner: Shanghai Caohejing Emerging Technology Development Zone Development Co., Ltd.

Type of owner: Local utility company

Total cooling load: $39.9 \mathrm{MW}$

Total cooling area: 0.48 million $\mathrm{m}^{2}$

Overall technology:DHCS

Cooling technology: Electric chillers combined with ice storage

Temperature: $\quad 1.5^{\circ} / 12.5^{\circ}$ (supply/return)
Implemented 
Shanghai Hongqiao

CBD

(Yang 2015; Li

2013)
Project owner:

Type of owner:

Total cooling load:

Total cooling area: 1.9 million

Overall technology: CCHP

Cooling technology: Absorption chillers and electric chillers

Temperature: $\quad$ Supply $6^{\circ} \mathrm{C}$, return $13^{\circ} \mathrm{C}$
Implemented

2013

Project owner: Jingneng Future Gas \& CHP Plant

Type of owner: Energy investor

Total cooling load: N/A

Total cooling area: 1.7 million $\mathrm{m}^{2}$

Overall technology: $\mathrm{CCHP}$

Cooling technology: Absorption chiller and electric heat pump/chiller (including ground-source heat pump/chiller)

Temperature: $\quad$ Supply $3^{\circ} \mathrm{C}$, return $13^{\circ} \mathrm{C}$

\section{Suzhou Science and Education Innovation Core Area}

Project owner: China-Singapore Suzhou Industrial

Type of owner: $\quad$ Local utility company

Total cooling load: $88 \mathrm{MW}$

Total cooling area: 1.1 million $\mathrm{m}^{2}$

Ongoing

2014

Overall technology: $\mathrm{CHP}$

Cooling technology: Absorption chiller

Temperature: N/A

Shenzheng Qianhai

Project owner:

Type of owner:

Total cooling load:

Total cooling area: 27 million $\mathrm{m}^{2}$

Cooling technology: Electric chillers combined

Temperature: N/A with ice storage at the present stage 
Ai Zhong Fan. 2014. Operation Optimization of District Heating and Cooling System of Wuhan Optics Valley Financial Harbor Phase. District Energy, November: 51-53.

Amecke, H., J. Deason, A. Hobbs, A. Novikova, X. Yang, and S. Zhang. 2013. Climate Policy Initiative (CPI) Report: Buildings Energy Efficiency in China, Germany and the United States. San Francisco: CPI.

Dong Baochun. 2011. Pudong Airport Terminal Energy Efficient Operation of HVAC System. Power and Energy, June: 240-243.

Enwave Chicago (enwavechicago.com)

Eom, J., P. Kyle, L. E. Clark, P. L. Patel, and S. H. Kim. 2012. China's Building Energy Use: A Long-Term Perspective based on a Detailed Assessment. Report prepared for the US Department of Energy. January

Federal Climate Complex in Asheville, North Carolina, US

Fu Jianping and $\mathrm{Wu}$ Shusheng. 2011. The Energy Planning of Guangzhou University Town. Building Energy \& Environment, August: 42-44.

Gao Zhiqiang, Gu Weixin, He Yan, Shou Weiwei, ZHU Nanjun, Bian Zhimei, 2010. Design and Application of Energy Centre Utilizing External-Melt Ice Storage System. Journal of HVEAC, June: 82-86.

Global Buildings Performance Network. 2012. Building Energy Efficiency Policies in China. France.

Gu Ming, Ma Hongquan, Wang Yong, 2010. The Key Technology of Yangtze River Water-Source Heat Pump and An Engineering Case. Building Energy $\mathcal{E} t$ Environment, August: 38-42.

Gu Weixin, Chen Shuihua, Jin Lingpeng, 2011. Energy Management System of Air Conditioning of District Cooling in Caohejing Modern Service Industry Aggregation. Refrigeration Air-conditioning \& Electric Power Machinery, No. 5: 45-48.

International District Energy Association (IDEA). 2008. District Cooling Best Practice Guide. 1st ed. Westborough, Massachusetts: IDEA.

International Energy Agency (IEA). Implementing Agreement on District Heating and Cooling Including Combined Heat and Power. iea-dhc.org

Japan for Sustainability (JFS). 2009. Japan's District Heating and Cooling Systems. JFS Newsletter, No. 82 (June).

Japan Heat Service Utilities Association. 2008. Heat Supply Business Guide. Tokyo. 
Japan Heat Supply Business Association (www.jdhc.or.jp)

Leng Yanfeng, Zhao Hui, Yuan Rubing, 2010. River Source Heat Pump Project of the Chongqing Grand Theatre. Construction Science and Technology, No. 18: 64-67.

Li He. 2013. HVAC Design for Hongqiao Libao Plaza Project of Shanghai Hongqiao CBD First Phase 01 Plot. Refrigeration Air-conditioning \& Electric Power Machinery, No. 2: 69-75. Liu Chuanju, Lu Qiongwen, Li Weiye, Liu Dong, Hu Zhihong, 2005. Application Study on Economic Operation of District Cooling System: Summary of Research on DHC Economic Operation in Pudong International Airport. Energy Technology, April: 81-83.

Ma Hongquan. 2009. Present Status and Prospects of District Cooling System. Journal of HVEAC, October: 52-59.

Ma Hongquan, Yu Songtao, Zhang Weiwei, Zhang Jianzhong, 2011. The Biggest District Cooling and Heating Project for River Source Heat Pump in Jiangsu Province. Construction Science and Technology, No. 4: 42-43.

Marafeq Qatar. 2015. District Cooling: GCC [Gulf Cooperation Council] and Qatar.

Qiu Dong. 2007. Introduction on District Cooling-Supply in the Guangzhou University City. Refrigeration Air-conditioning \& Electric Power Machinery, No. 4: 76-79.

Renewable Smart Cooling for Urban Europe (RESCUE). 2014. Capital Cooling, WP 2, EU District Cooling Market and Trends.

Shen Jiashui. 1985. The Introduction of Japanese Air-Conditioning Status. Refrigeration,No.4.

Song Xiaochun. 2004. Technical Analysis of District Cooling Design for West Zone of Zhongguancun. Journal of HVEA AC, October: 88-90.

Song Xiaochun, Li Juan, Xia Shuwei, Zhuang Jing, Tang Xuezong, 2010. Design of Yalongwan District Cooling System. Journal of HV\&AC, June: 57-71.

Song Xiaochun, Wei Hang, Li Juan, He Shu, 2010. Research of District Cooling Scheme for an Office Area in Haikou. Journal of HVEAC, June: 97-102.

Sui Xiaofeng, Jiang Weiwei, He Jichao, Li Zhuxuan, 2012. Application Research on District Cooling in the Lize Financial Business District. Construction $\mathcal{E}$ Design for Project, No. 11: 181-185.

Sun Yuying, Zhao Yaohua, Wang Yingjie, Ni Yongfeng, Wang Wei, 2012. Automatic Control System Design and Application Analysis on Yalong Bay Ice Storage District Cooling System. Building Science, August: 104-108.

Tan Futai. 2009. Energy Saving Optimization of District Cooling System in Guangzhou University City. Energy Conservation Technology, July: 371-374. 
Thornton, Robert. 2005. IDEA Report: The District Energy Industry.

Wang Yuyan, Zhang Jianzhong, and Huang Hu. 2009. Optimize District Cooling and Heating System of Nanjing Gulou Software Park. Journal of HVEAC, July: 95-98.

Wu Xiaoting, Wang Yan, Wang Peng, Zhao Bin, Zhao Dailiang, 2010. Design Consideration of Refrigeration Plant 3 of District Cooling for Guangzhou Higher Education Mega Center. Journal of HVEtAC, June: 23-27.

Xu Wei, Sun Zhongwei, Feng Xiaomei, Du Guofu, Li Yi, 2013. Development Status and Prospect of District Energy Building Application Technology. Building Science, October: 85-89.

Yang Guangmei. 2015. Introduction of Centralized Energy Supply System in Core Area of Hongqiao CBD. Green Building, No. 4: 15-17.

Yang, H., J. Burnett, K. Lau, and L. Lu. 2001. Comparing Central and Split AirConditioning Systems. ASHRAE Journal, May.

Yin Ping. 2013. Research of Combined Cooling Heating and Power System (4): District Cooling and Heating. Journal of HV\& AC, July: 10-17. Zhao Huien. 2011. Business Research of District Cooling and Heating System. Modern Business Trade Industry, No. 23: 75-77.

Zhao Huien, 2011. Operation Research for the District Cooling and Heating System: A Case Study for River Source Heat Pump of the District Cooling and Heating Project in Jiangbei CBD, Chongqing. Modern Business Trade Industry, No. 23: 75-77.

Zhao Jiancheng and Niu Limin. 2004. The District Cooling System of Cooling Production Adopted External-Melt Ice: Ice Storage. Building Science, August: 194-197. 



\section{District Cooling in the People's Republic of China Status and Development Potential}

This report defines the concept of district cooling and summarizes its benefits and challenges then presents technologies used in the process-including stand-alone as well as integrated or cogeneration (or even trigeneration) solutions. It also discusses business models followed in the district cooling sector and considers the financial feasibility of district cooling projects and goes over the various regulations regarding district cooling. The report then looks into how district cooling has developed worldwide and examines the district cooling market in the People's Republic of China, then recommends steps that should be taken for the further development of district cooling in the country.

\section{About the Asian Development Bank}

ADB's vision is an Asia and Pacific region free of poverty. Its mission is to help its developing member countries reduce poverty and improve the quality of life of their people. Despite the region's many successes, it remains home to a large share of the world's poor. ADB is committed to reducing poverty through inclusive economic growth, environmentally sustainable growth, and regional integration.

Based in Manila, ADB is owned by 67 members, including 48 from the region. Its main instruments for helping its developing member countries are policy dialogue, loans, equity investments, guarantees, grants, and technical assistance. 